\title{
Marine Geology and Earthquake Hazards of the San Pedro Shelf Region, Southern California
}

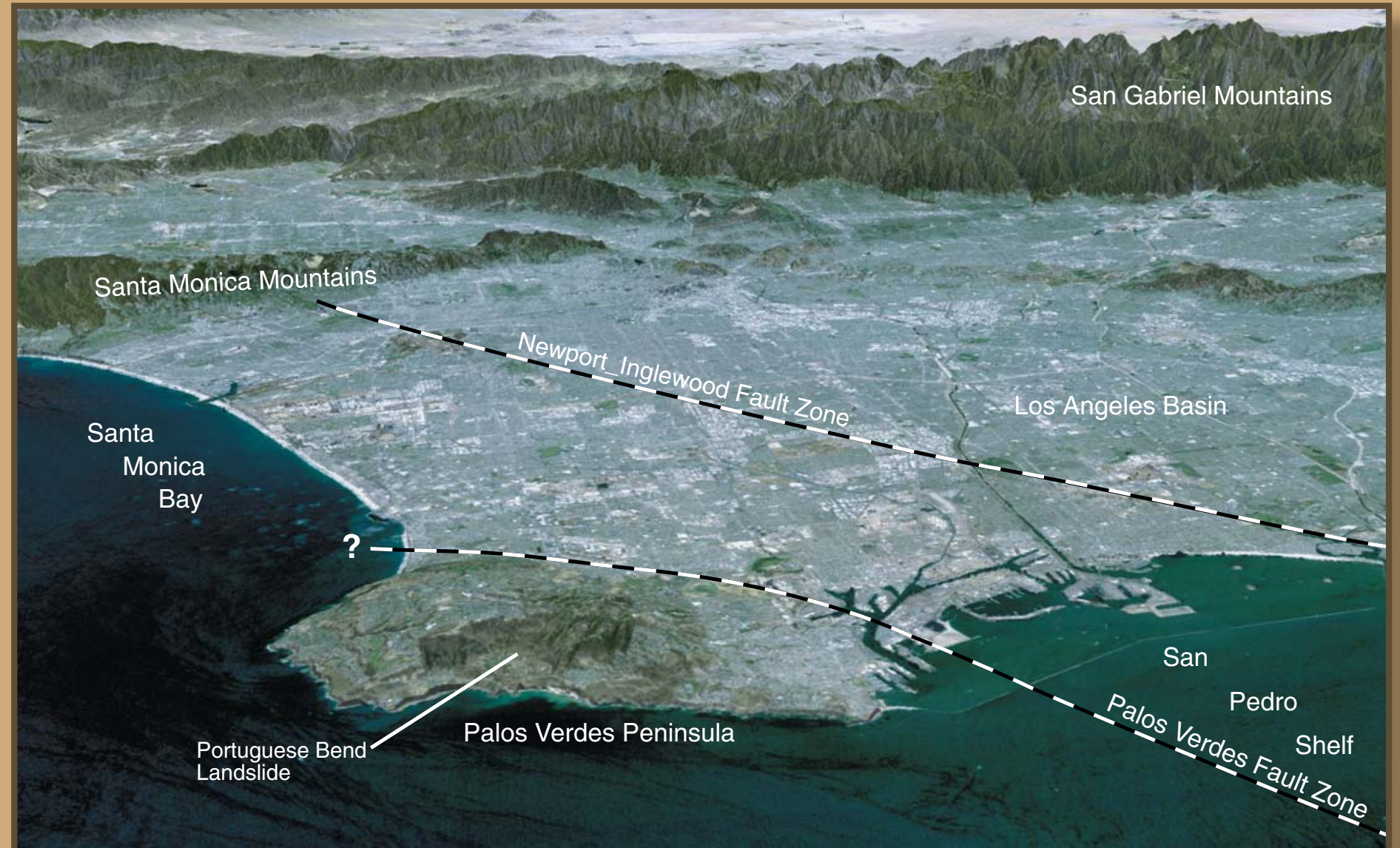

San Pedro Basin

Professional Paper 1687

U.S. Department of the Interior

U.S. Geological Survey 


\section{Marine Geology and Earthquake Hazards of the San Pedro Shelf Region, Southern California}

Michael A. Fisher, William R. Normark, Victoria E. Langenheim, Andrew J. Calvert, and Ray Sliter

Offshore geophysical and geological data are combined to determine the distribution of potential earthquake faults near the Los Angeles urban area.

Professional Paper 1687 


\title{
U.S. Department of the Interior \\ Gale A. Norton, Secretary
}

\section{U.S. Geological Survey Charles G. Groat, Director}

\author{
U.S. Geological Survey, Reston, Virginia: 2004 \\ For sale by U.S. Geological Survey Information Services \\ Box 25286, Denver Federal Center \\ Denver, CO 80225 \\ This report and any updates to it are available online at: \\ http://geopubs.wr.usgs.gov/prof-paper/p1687/ \\ Additional USGS publications can be found at: \\ http://geology.usgs.gov/products.html \\ For more information about the USGS and its products: \\ Telephone: 1-888-ASK-USGS (1-888-275-8747) \\ World Wide Web: http://www.usgs.gov/
}

\begin{abstract}
Any use of trade, product, or firm names in this publication is for descriptive purposes only and does not imply endorsement of the U.S. Government.

Although this report is in the public domain, it contains copyrighted materials that are noted in the text. Permission to reproduce those items must be secured from the individual copyright owners.
\end{abstract}

\section{Cataloging-in-publication data are on file with the Library of Congress (URL http://www.loc.gov/).}

Published in the Western Region, Menlo Park, California

Manuscript approved for publication, December 15, 2003

Text edited by Peter $\mathrm{H}$. Stauffer

Production and design by Sara Boore

Front Cover Oblique image, looking north-northeast, of the Los Angeles region, California, and the adjacent Pacific 0 cean, showing major geographic features and locations of main faults. Width of image is about $70 \mathrm{~km}$, center of image located at about $34^{\circ} \mathrm{N}, 118.2^{\circ} \mathrm{W}$. Image consists of an enhanced Landsat 5 satellite image (Bands 3, 2, and 1 as red, green, and blue, respectively) draped over topography from Space Shuttle radar data, with vertical exaggeration of 1.5 times. From National Aeronautical and Space Administration (NASA), available (without annotations) from: http://www.jpl.nasa.gov/srtm/california.html\#PIA03348. 


\section{Contents}

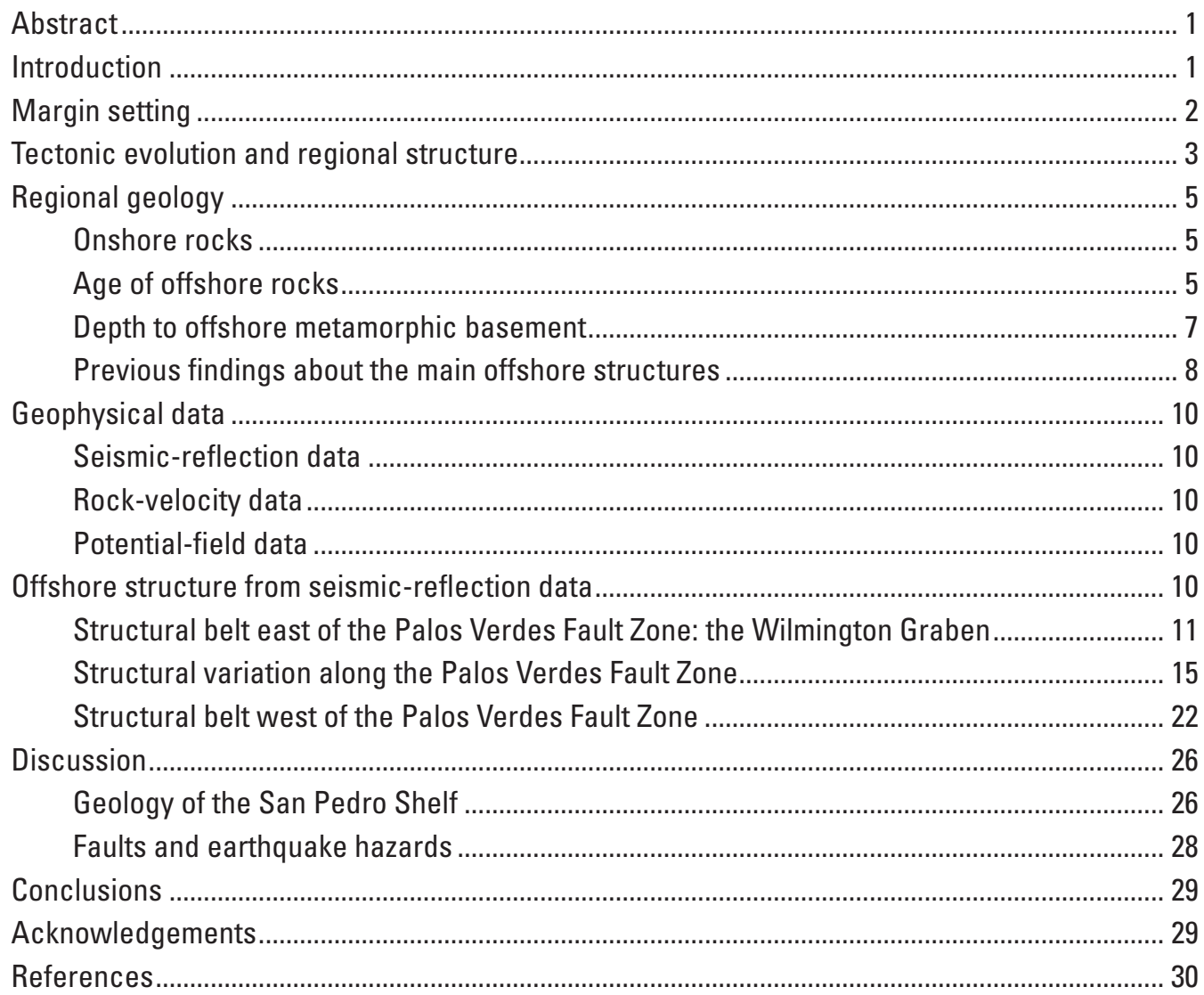

\section{Plates}

[in pocket]

1. Seismic-reflection sections showing structural variations along the Palos Verdes Fault Zone, Southern California

2. Post-stack migrated and depth-converted multichannel seismic-reflection sections from the San Pedro Shelf, Southern California

\section{Figures}

1. Location map of the study area near the San Pedro Shelf

2. Map showing tracklines of small-airgun seismic-reflection surveys in the study area during 1997-8 by the U.S. Geological Survey

3. Map showing locations of regional cross sections in the study area, and diagram of Miocene and younger stratigraphy

4. Cross sections comparing seismic-reflection data from this study with stratigraphic information from the Beta oil field

5. Deep-crustal seismic-reflection data and simplified composite cross section across the San Pedro Shelf and the Palos Verdes Fault Zone. 
6. Tomographic velocities across the San Pedro Basin and Shelf derived from data obtained during the LARSE experiment

7. Velocity-depth function derived from digitized and averaged sonic logs from five wells.

8. Aeromagnetic anomaly map and isostatic gravity map of the study area

9. Index map of detailed seismic-reflection sections over selected features below the San Pedro Shelf and Lasuen Knoll.

10. Seismic section over the Palos Verdes Fault Zone and Wilmington Graben under the San Pedro Shelf.

11. Seismic sections showing the geologic structure near Dana Point............................... 14

12. Detailed seismic section over the Palos Verdes Fault Zone ............................................ 15

13. Detailed seismic sections over the Palos Verdes Fault Zone .......................................... 16

14. Oblique shaded-relief diagrams of the San Pedro Shelf and Lasuen Knoll.................... 18

15. Detailed seismic section over the Palos Verdes Fault Zone under the bathymetric saddle between the San Pedro Shelf and Lasuen Knoll.............................. 19

16. Detailed seismic section over the Palos Verdes Fault Zone and Lasuen Knoll .............. 19

17. Detailed seismic section from near the crest of Lasuen Knoll ............................................ 20

18. Detailed seismic section over the northwestern part of Lasuen Knoll............................ 21

19. Map summarizing the main known and inferred structures in the region of the San

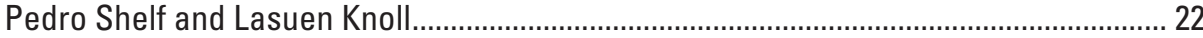

20. Detailed seismic section from the San Pedro Shelf .................................................. 23

21. Seismic sections over the slope west of the San Pedro Shelf, showing Miocene(?) rocks.

22. Seismic section over the slope west of the San Pedro Shelf, showing the lower-slope

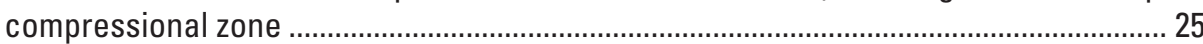

23. Seismic sections over the slope northwest of the San Pedro Shelf and the San Pedro Basin.....

24. Magnetic and gravity models along seismic sections 115 and 200 ................................ 27 


\title{
Marine Geology and Earthquake Hazards of the San Pedro Shelf Region, Southern California
}

\author{
By Michael A. Fisher ${ }^{1}$, William R. Normark', Victoria E. Langenheim', Andrew J. Calvert², and Ray Sliter ${ }^{1}$
}

\section{Abstract}

High-resolution seismic-reflection data have been combined with a variety of other geophysical and geological data to interpret the offshore structure and earthquake hazards of the San Pedro Shelf, near Los Angeles, California. Prominent structures investigated include the Wilmington Graben, the Palos Verdes Fault Zone, various faults below the western part of the shelf and slope, and the deep-water San Pedro Basin. The structure of the Palos Verdes Fault Zone changes markedly southeastward across the San Pedro Shelf and slope. Under the northern part of the shelf, this fault zone includes several strands, but the main strand dips west and is probably an oblique-slip fault. Under the slope, this fault zone consists of several fault strands having normal separation, most of which dip moderately east. To the southeast near Lasuen Knoll, the Palos Verdes Fault Zone locally is a low-angle fault that dips east, but elsewhere near this knoll the fault appears to dip steeply. Fresh sea-floor scarps near Lasuen Knoll indicate recent fault movement. The observed regional structural variation along the Palos Verdes Fault Zone is explained as the result of changes in strike and fault geometry along a master strike-slip fault at depth. The shallow summit and possible wavecut terraces on Lasuen knoll indicate subaerial exposure during the last sea-level lowstand. Modeling of aeromagnetic data indicates the presence of a large magnetic body under the western part of the San Pedro Shelf and upper slope. This is interpreted to be a thick body of basalt of Miocene(?) age. Reflective sedimentary rocks overlying the basalt are tightly folded, whereas folds in sedimentary rocks east of the basalt have longer wavelengths. This difference might mean that the basalt was more competent during folding than the encasing sedimentary rocks. West of the Palos Verdes Fault Zone, other northwest-striking faults deform the outer shelf and slope. Evidence for recent movement along these faults is equivocal, because age dates on deformed or offset sediment are lacking.

${ }^{1}$ U.S. Geological Survey

345 Middlefield Road, MS 999 Menlo Park, CA, 94025

mfisher@usgs.gov, 650-329-5158

${ }^{2}$ Department of Earth Sciences

Simon Fraser University

Burnaby, B.C., V5A 1S6, Canada

\section{Introduction}

Numerous thrust and strike-slip faults cross cut the Los Angeles region (fig.1) and pose a significant earthquake hazard to this burgeoning population center (see, for example, Shaw and Suppe, 1996; Shaw and Shearer, 1999; Dolan and others, 2000; Weaver and Dolan, 2000; Tsutsumi and others, 2001). Much effort has been expended to locate and determine the displacement history of these faults; even so, a category of fault that remains poorly understood includes active offshore faults within about $50 \mathrm{~km}$ of the coast. Largely because of a lack of information, such faults are often omitted from models of tectonic evolution and estimates of seismic hazard.

Recent earthquakes at Whittier Narrows (1987, $\mathrm{M}_{\mathrm{L}}$ 5.9; Hauksson and others, 1988; Lin and Stein, 1989) and at Northridge (1994, Mw 6.7; Hauksson and others, 1995) provide a measure of the regional seismic hazard and the economic dislocation that can result from earthquakes along onshore faults. In comparison, historical seismicity indicates that offshore faults can unleash earthquakes with at least moderate magnitude, as shown by compilations of southern California seismicity (for example, Ziony and Jones, 1989; Jennings, 1994; Petersen and Wesnousky, 1994; Astiz and Shearer, 2000; Richards-Dinger and Shearer, 2000). In 1933, a large (Mw 6.4) earthquake struck near Long Beach, probably along the offshore part of the Newport-Inglewood strike-slip fault (Barrows, 1974; Hauksson and Gross, 1991). Offshore epicenters in and around the area of this study are diffuse but tend to cluster over the western San Pedro Shelf and eastern San Pedro Basin (fig. 1). Two moderate, offshore earthquakes occurred near the coastal town of Malibu (M 5.2 in 1979 and M 5.0 in 1989; see inset to fig. 1). No large earthquakes have occurred in the recent past along the Palos Verdes Fault Zone, which strikes generally southeast across the San Pedro Shelf and nearshore areas (fig. 1). However, McNeilan and others (1996) estimate that this fault could produce an earthquake as large as about M 7.

The dearth of information about Holocene activity along offshore faults in this region provided the impetus to gain a more complete understanding of the offshore geologic structure. During 1998 through 2000, the U.S. Geological Survey collected high- and medium-resolution, marine seismic-reflection data (tracklines shown in fig. 2) with the goals of locating 
active faults and estimating their displacement histories. A related research goal is understanding the susceptibility of the offshore region to earthquake-induced landslides and consequent local tsunamis. The Portuguese Bend landslide on the Palos Verdes Peninsula (see, for example, Woodring and others, 1946) and offshore landslides evident in seismic-reflection and multibeam-bathymetric data (for example, Locat and Lee, 2002), indicate that sediment under the sea floor is locally susceptible to catastrophic downslope movement. The submarine Palos Verdes debris avalanche, which displaced more than a cubic kilometer of slope sediment, occurred 7,500 years ago (Normark and others, 2002).

This study focuses on the structure and stratigraphy southeastward from the Palos Verdes Peninsula to near Dana Point (fig. 1). Within the study area, the Palos Verdes Fault (Fischer and others, 1987; McNeilan and others, 1996) and the Newport-Inglewood Fault (Barrows, 1974; Fischer, 1992) play key roles in the regional earthquake hazard.

\section{Margin Setting}

The study area encompasses the San Pedro continental shelf and the eastern part of the deep-water San Pedro Basin, lying west and southwest of the shelf (fig. 1). This area straddles the tectonic boundary between the Los Angeles Basin and the extensive California Continental Borderland (CCB). The Los Angeles Basin is filled with Miocene and younger rocks, at least $10 \mathrm{~km}$ thick, and the basin extends westward to near the Palos Verdes Fault Zone (Wright, 1991). West of the Los Angeles Basin, the CCB is $200 \mathrm{~km}$ wide and ends in the west at the Patton Escarpment.

Within the study area, rocks under the Palos Verdes Peninsula have long attracted the attention of geologists, because rapid uplift during the Quaternary caused an impressive flight of wavecut terraces to develop (Woodring and others, 1946; Bryan, 1987; Ward and Valensise, 1994). A concern of seismologists is that this intense vertical deforma-

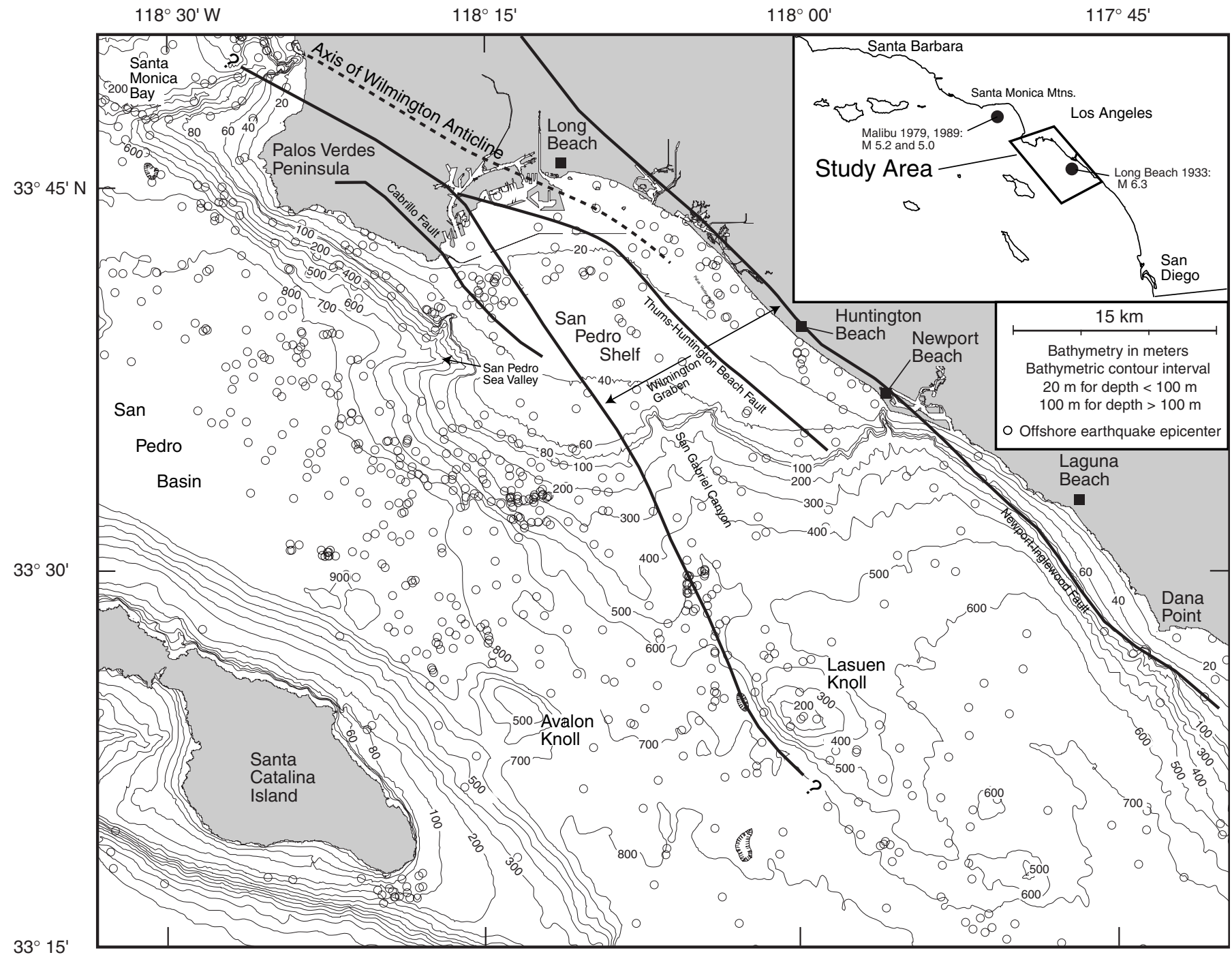

Figure 1. The study area near the San Pedro Shelf, showing the main faults, earthquake epicenters (1978-1998, from Richards-Dingler and Shearer, 2000), and bathymetry. 
tion may extend south of the Palos Verdes Peninsula to involve offshore faults. This possibility has been difficult to evaluate, given the generally featureless morphology of the San Pedro Shelf, which is broad, flat, and shallow. Most of it is less than $50 \mathrm{~m}$ deep (fig. 1), so it is unclear whether deformation rates measured onshore characterize offshore areas.

In contrast to the flat expanse of the San Pedro Shelf, the rest of the study area is characterized by varied topography. The San Pedro Shelf is bordered to the west and southeast by a steep slope (fig. 1). At the west end of the shelf, the San Pedro Sea Valley, a deep notch cut eastward into the shelf, is structurally controlled. South of the San Pedro Sea Valley, the San Gabriel Canyon incises the shelf break. This canyon extends south from the shelf edge, crosses the continental slope, and feeds sinuous turbidite channels on the floor of the San Pedro Basin. East of the San Gabriel canyon, the numerous tributaries of the Newport Canyon head near the coast at Newport
Beach, where the shelf narrows greatly. A narrow shelf extends southeastward beyond the limit of the study area.

\section{Tectonic Evolution and Regional Structure}

Before the Miocene, the tectonic regime in the study area involved the eastward subduction of the Farallon oceanic plate beneath the area now occupied by the CCB (Atwater, 1970; Engebretson and others, 1985; Schwartz and Colburn, 1987; Wright, 1991). Subduction continued until the early Miocene, when the part of the Farallon Plate that lay west of southern California stopped subducting and began to move northward with the Pacific Plate (Nicholson and others, 1994). During this tectonic transition, regional oblique rifting and strike-slip deformation replaced

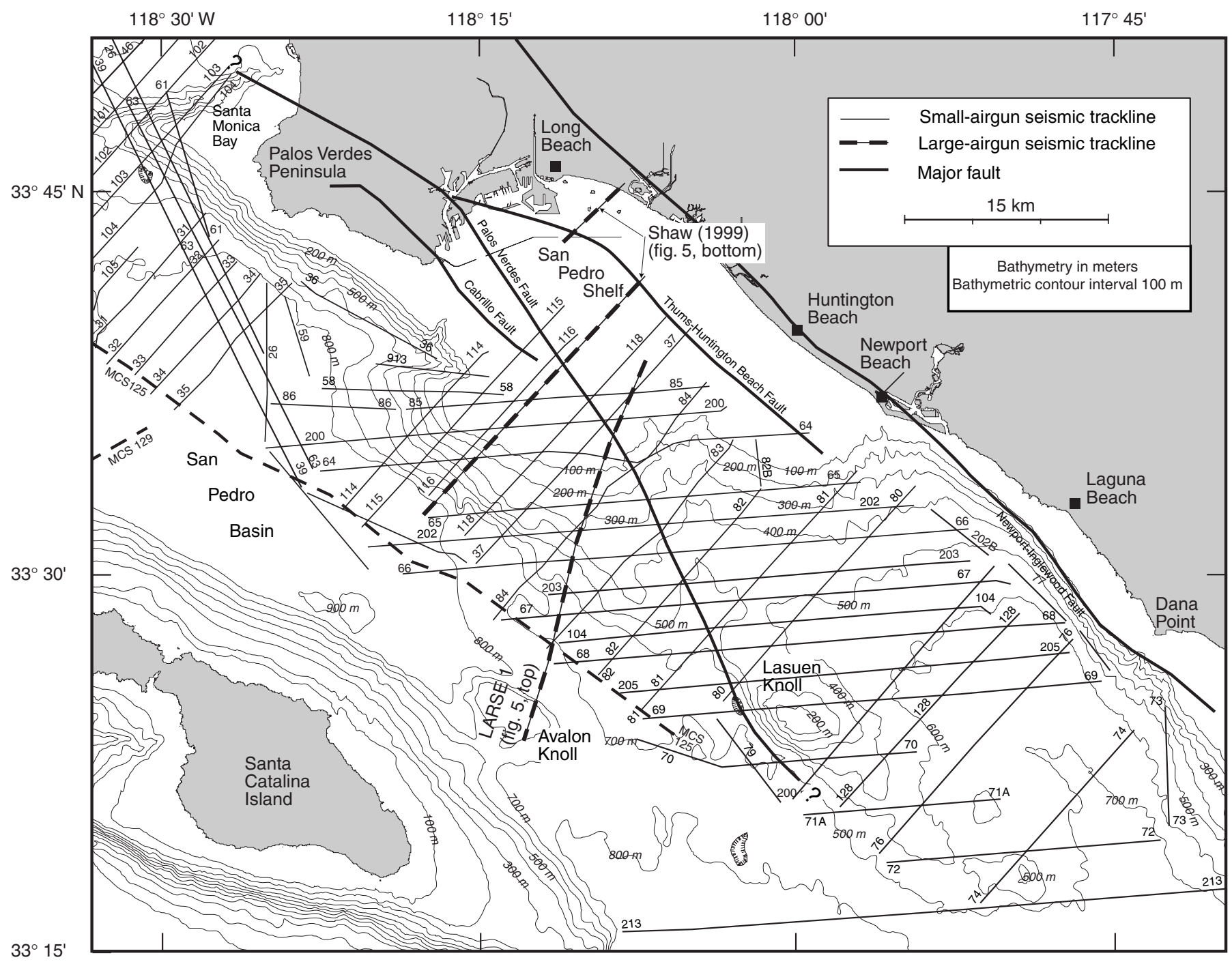

Figure 2. Tracklines of small-airgun seismic-reflection data obtained during 1997-8 by the U.S. Geological Survey (USGS). These data were obtained with a 240 -m-long streamer and with either a generator-injector airgun (each chamber was $35 \mathrm{in}^{3}$ ) or a $40 \mathrm{in}^{3} \mathrm{Bolt}$ airgun. Location of LARSE 1 deep crustal seismic-reflection line is also shown (Brocher and others, 1995) and seismic-reflection line of Shaw (1999). MCS 125 and MCS 129 indicate multichannel seismic-reflection data collected by the USGS during 1990. 
margin-normal subduction. The resulting oblique extension of the margin of North America is thought to have occurred simultaneously with the clockwise rotation of the Transverse Ranges (Luyendyk and others, 1980, 1985; Kamerling and Luyendyk, 1985; Hornafius and others, 1986). The upper plate of the subduction zone underwent intense crustal extension (Vedder, 1987; Wright, 1991; Crouch and Suppe, 1993; Nicholson and others, 1994; Bohannon and Geist, 1998; ten Brink and others, 2000; Bjorklund and others, 2002), so that locally the continental margin may have doubled in width. Blueschist- and amphibolite-facies metamorphic rocks from the former subduction zone were uplifted from lower crustal depths and exposed at the surface. These rocks currently crop out as the Catalina Schist, and they make up the basement complex beneath much of the inner $\mathrm{CCB}$, including this study area. Regional uplift of the Catalina Schist during the early Miocene accounts for the absence of sedimentary rocks of this and older age beneath the inner CCB. As the heat-flow anomaly associated with the crustal extension dissipated, the extended region subsided, and metamorphic basement rocks were buried beneath locally thick sediment.

Volcanism followed the crustal extension (Dickinson, 1997; Bjorklund and others, 2002). Middle Miocene volcanic rocks, including pillow basalt and basalt sills, are exposed on the Palos Verdes Peninsula (fig. 3A; Woodring and others, 1946; Conrad and Ehlig, 1987; Stanley and others, 2000; McCulloh and others, 2002). As is shown below, some of these volcanic rocks produce offshore aeromagnetic anomalies.

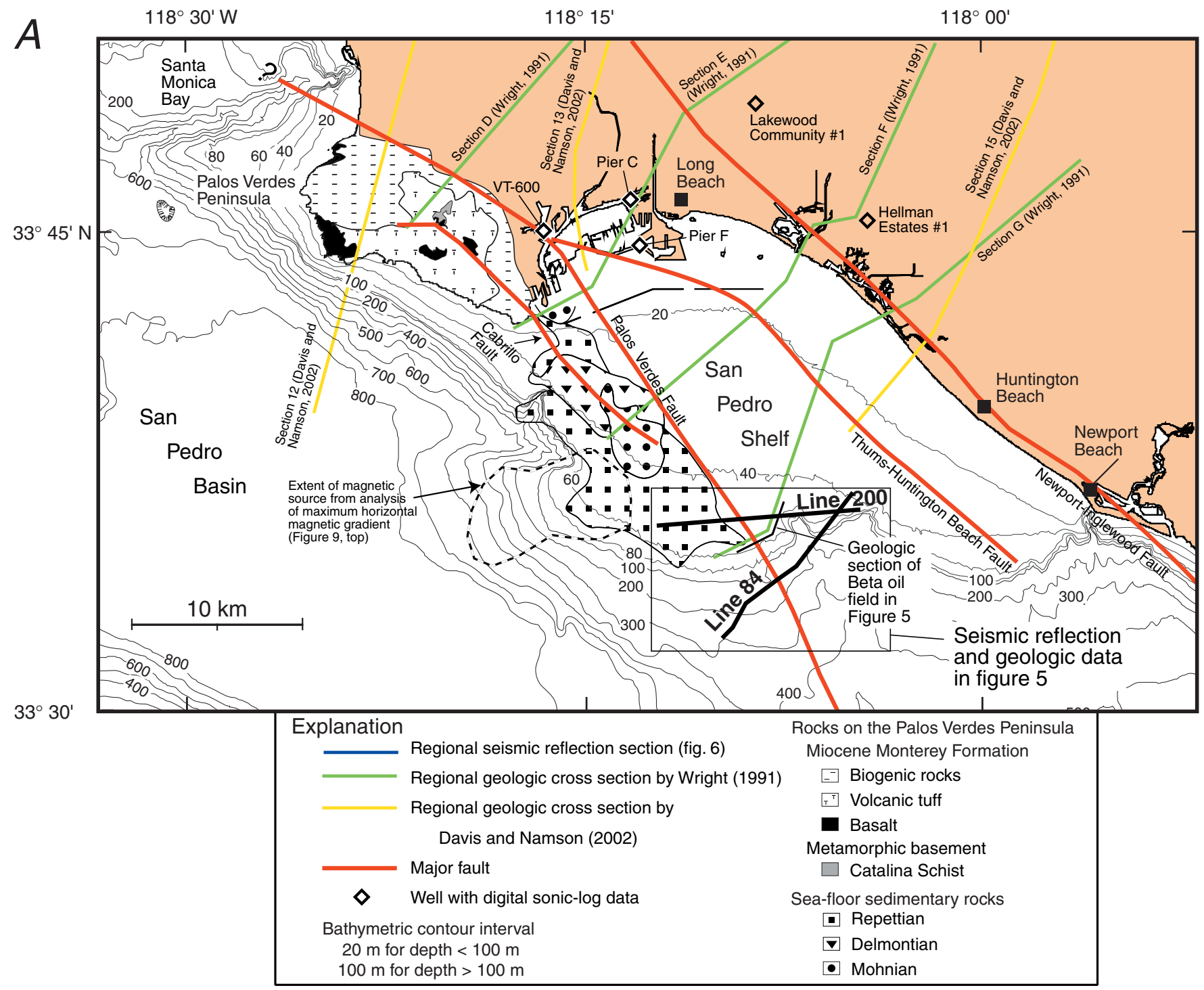

Figure 3. Cross sections and stratigraphy in the study area. $A$, Locations of regional cross sections compiled by various authors and discussed in the text. Also shown are locations of wells from which sonic-log data were obtained. A cross section through the Beta Oil field (Wright, 1991) shows the approximate age of basin fill in figure 4. Biostratigraphic data from strata exposed at the sea floor are from Nardin and Henyey (1978). Onshore geology of the Palos Verdes Peninsula is from Woodring and others (1946). $B$, Stratigraphic nomenclature for Miocene and younger rocks in the study area (after Blake, 1991; Barron and Isaacs, 2001). 
In late Pliocene and Quaternary time, mainly the past 4 m.y., the extended rocks of the continental margin were deformed by regional transpression (Atwater, 1970; Wright, 1991; Crouch and Suppe, 1993; Bohannon and Geist, 1998). The Pliocene transition in regional strain proceeded gradually and produced a structural grain that includes northwesttrending compressional and strike-slip faults (Hauksson, 1990; Wright, 1991; Dolan and others, 1995; Shaw and Suppe, 1996; Schneider and others, 1996; Walls and others, 1998; Bohannon and Geist, 1998; Shaw and Shearer, 1999; Argus and others, 1999). During this tectonic transition, some middle Miocene normal and oblique-normal faults were reactivated as reverse and strike-slip faults. Blind thrust faults and fault-propagation folds also may have begun to form offshore and beneath the densely populated Los Angeles region (see, for example, Namson and Davis, 1990; Shaw and Suppe, 1996).

Evidence for the Pliocene onset of this transpressive deformation comes from oil-industry wells that penetrate into the large Wilmington Anticline. This anticline (fig.1) deforms rocks northeast of the study area but did not exist before the deposition of upper Miocene and lower Pliocene rocks (Olson, 1974).Transpressive folding of this anticline apparently was completed by the end of the late Pliocene (Truex, 1973).

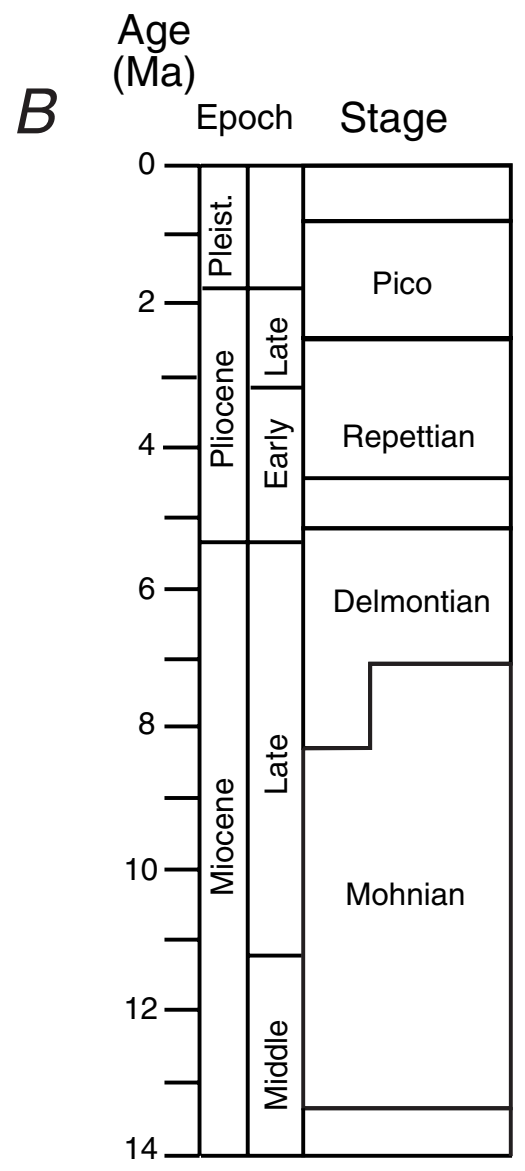

Figure 3-Continued

\section{Regional Geology}

\section{Onshore Rocks}

Metamorphic basement rocks exposed on the Palos Verdes Peninsula are overlain with marked unconformity by a sedimentary succession, middle Miocene through Pliocene in age, that is probably similar to some rock sequences revealed in seismic-reflection data collected offshore (for example, Fischer and others, 1987; Wright, 1991). Under the peninsula, middle and late Miocene deep-marine rocks form a thick, heterogeneous sequence assigned to the Monterey Formation (Woodring and others, 1946; Conrad and Ehlig, 1987; Schwartz and Colburn, 1987; Blake, 1991; Isaacs, 2001; Barron and Isaacs, 2001) (figs. $3 A, B$ ). This formation was deposited extensively in western California and is exposed on the Palos Verdes Peninsula, where it includes three main lithologic units. The bottom unit of the Monterey Formation rests unconformably on metamorphic basement and includes not only cherty and phosphatic shale but also volcanic tuff and basalt. The volcanic rocks have been dated to between 15 and $14 \mathrm{Ma}$ (middle Miocene; Conrad and Ehlig, 1987; Stanley and others, 2000) (fig. 3B). The middle rock unit of the Monterey Formation is diatomite. This unit is important to the interpretation of offshore seismic-reflection data, because the low density and low acoustic velocity of diatomite, relative to such properties in over- and underlying rock units, likely cause strong seismic reflections. The top unit of the Monterey Formation is mudstone.

Lower Pliocene rocks on the Palos Verdes Peninsula unconformably overlie the Monterey Formation, and upper Pliocene rocks are absent. This stratal succession resulted because the area of the peninsula appears to have been a submarine high during the early Pliocene and received some sediment, but during the late Pliocene, this high apparently was exposed subaerially and eroded (Henry, 1987). Thick Pliocene strata in the Los Angeles Basin, east of the Palos Verdes Peninsula, were deposited predominantly in a deep marine basin. Pleistocene and Holocene sediment in the Los Angeles Basin was deposited atop a regional erosion surface. The upper part of the Pleistocene and Holocene rock sequence includes the transition from marine to generally nonmarine deposition.

\section{Age of Offshore Rocks}

The offshore stratigraphy is known primarily from oil industry coring and drilling. Numerous shallow cores, obtained south of the Palos Verdes Peninsula and west of the Palos Verdes Fault Zone, show that middle Miocene through Pliocene rocks are exposed at the sea-floor in a southeasttrending zone near the shelf break (Nardin and Henyey, 1978) (fig. 3A). These sea-floor rocks cause high backscatter in multibeam bathymetric data. We show below that seismic reflections from Miocene rocks are distinctive in that they 
are parallel, uniform in appearance, and continuous over long distances $(10-20 \mathrm{~km})$.

Other information concerning the age of offshore rocks comes from geologic cross sections (locations shown on fig. $3 A$ ) that are based on well data from the Beta oil field (Henry,
1987; figure 14 in Wright, 1991). Comparison of one cross section from Wright (1991) to depth-converted, U.S. Geological Survey seismic-reflection data (fig.4) reveals not only the probable thickness and age of rocks on opposite sides of the Palos Verdes Fault Zone but also the depth to crystalline base-

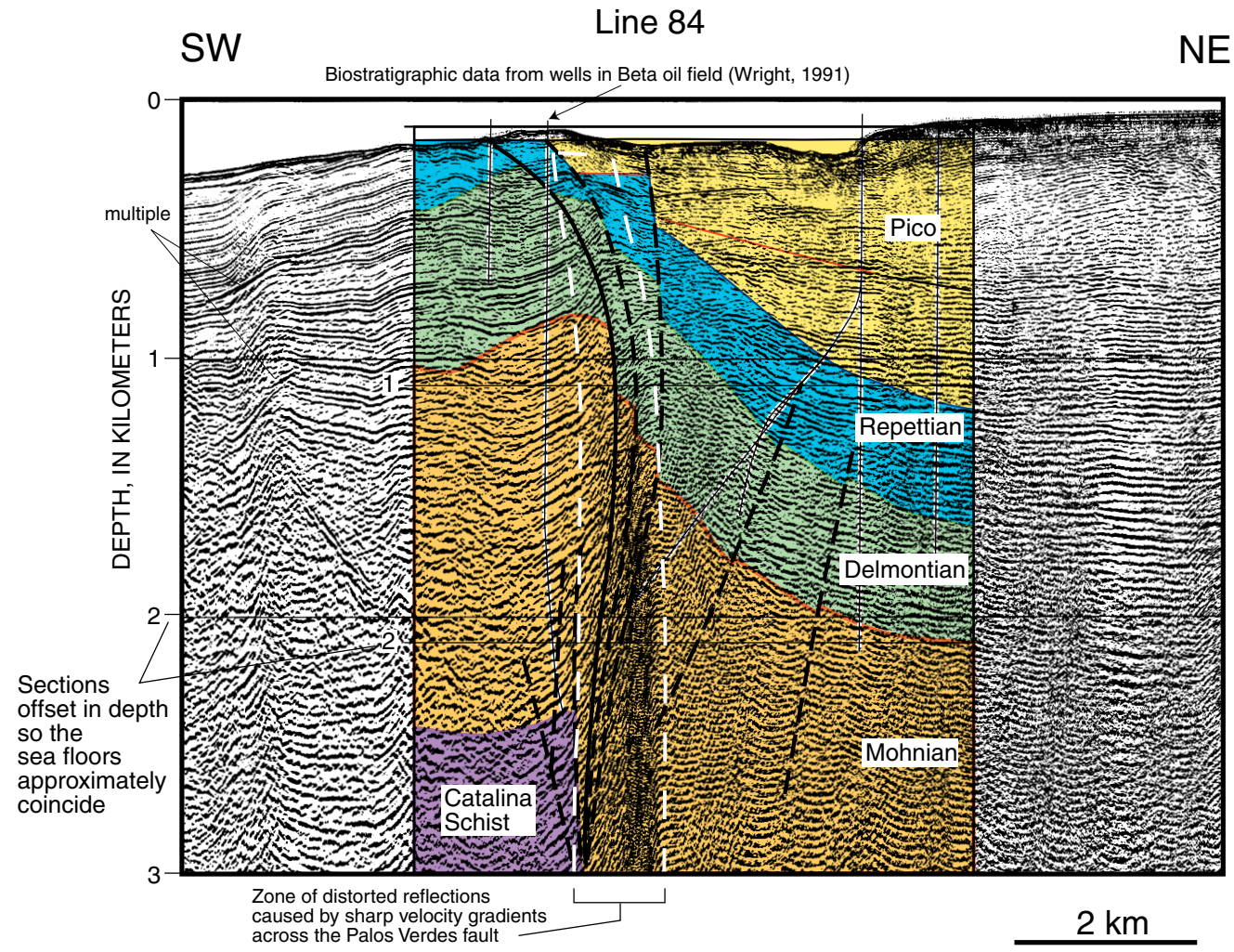

Line 200

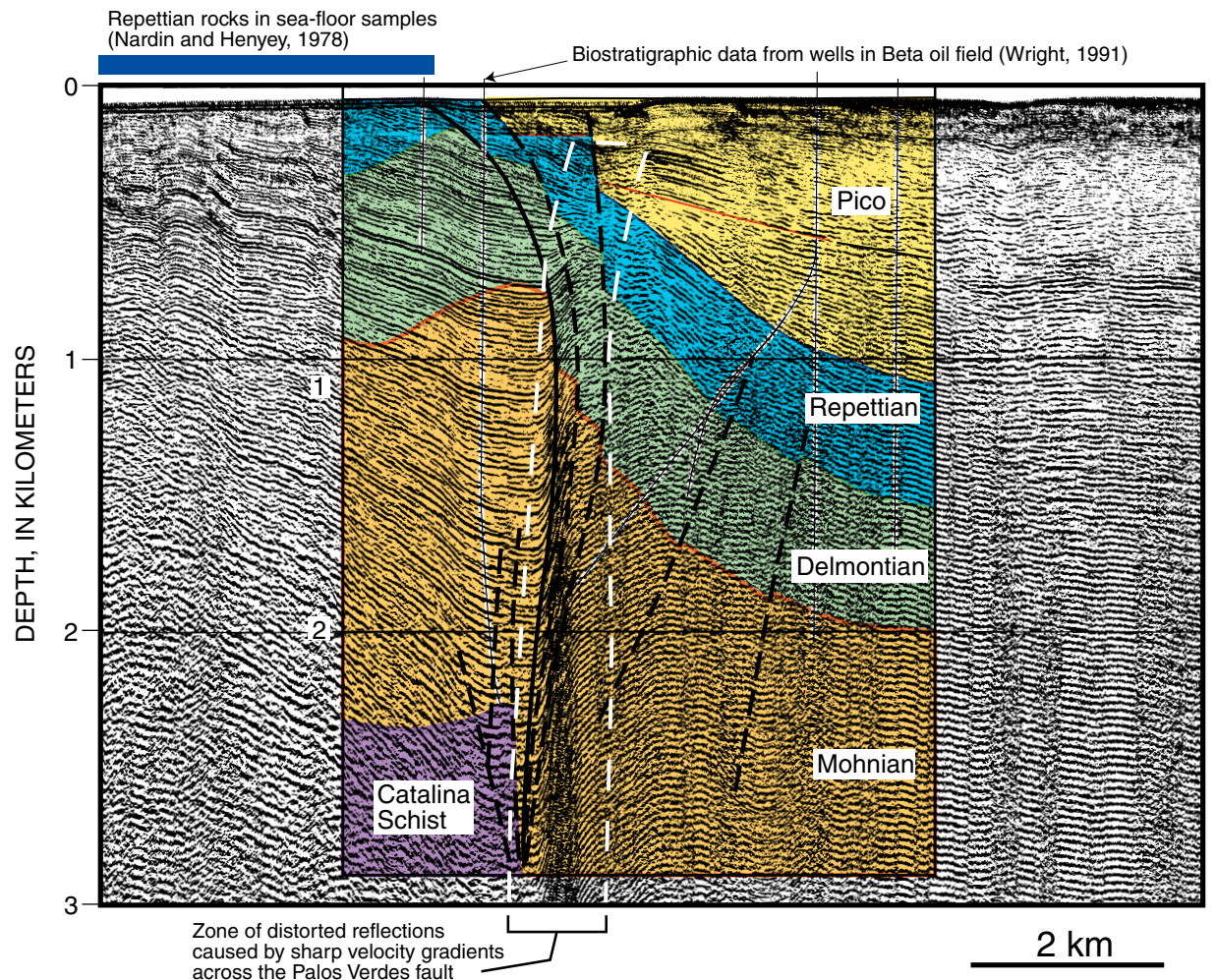

Figure 4. Comparison of depthconverted seismic-reflection data along two lines from this study with stratigraphic information (colors) from the Beta oil field (Wright, 1991) and age of sea-floor samples (Nardin and Henyey, 1978). Rocks west of the Palos Verdes Fault Zone are mainly Miocene and Pliocene in age, whereas thick late Pliocene and Quaternary rocks and sediment lie on this fault zone's east side. 
ment on the west side of the fault. The comparison indicates that near the Beta oil field and west of the Palos Verdes Fault Zone, Quaternary sediment is thin or absent and Miocene and Pliocene rocks are exposed at the sea floor. This exposure agrees with findings from the shallow coring mentioned above. East of the Palos Verdes Fault Zone, however, late Pliocene and Quaternary rocks and sediment aggregate in thickness to as much as $1.5 \mathrm{~km}$.

\section{Depth to Offshore Metamorphic Basement}

In general, clear reflections from the top of metamorphic basement are not apparent in the small-airgun seismic-reflection data described here, but evidence from rock outcrop, oil industry operations, and seismic-refraction data all indicate that this basement lies at relatively shallow depth $(<3 \mathrm{~km})$ beneath the shelf and slope.
Regionally, the depth to basement decreases westward from within the Los Angeles Basin toward the offshore study area, and basement deepens offshore southeastward from its outcrop on the Palos Verdes Peninsula (see, for example, Olson, 1974; Fischer and others, 1987; Wright, 1991). This configuration is demonstrated primarily by information compiled from oil industry sources. For example, regional cross sections (locations shown in fig. 3A) by several authors indicate that east of the Palos Verdes Fault Zone and Peninsula, the top of basement is mainly 1 to $1.5 \mathrm{~km}$ deep, except locally, where basement depth increases to about $3 \mathrm{~km}$ (section 12 of Davis and Namson, 2002). A cross section drawn through the Huntington Beach oil field (section 15 of Davis and Namson, 2002) indicates basement rocks at about $3 \mathrm{~km}$ depth, except along the NewportInglewood Fault, where basement may be more than $5 \mathrm{~km}$ deep.

Another regional cross section, constructed in part from depth-converted seismic-reflection data (Shaw, 1999; summarized in fig. 5, bottom; section location shown in fig. 2),

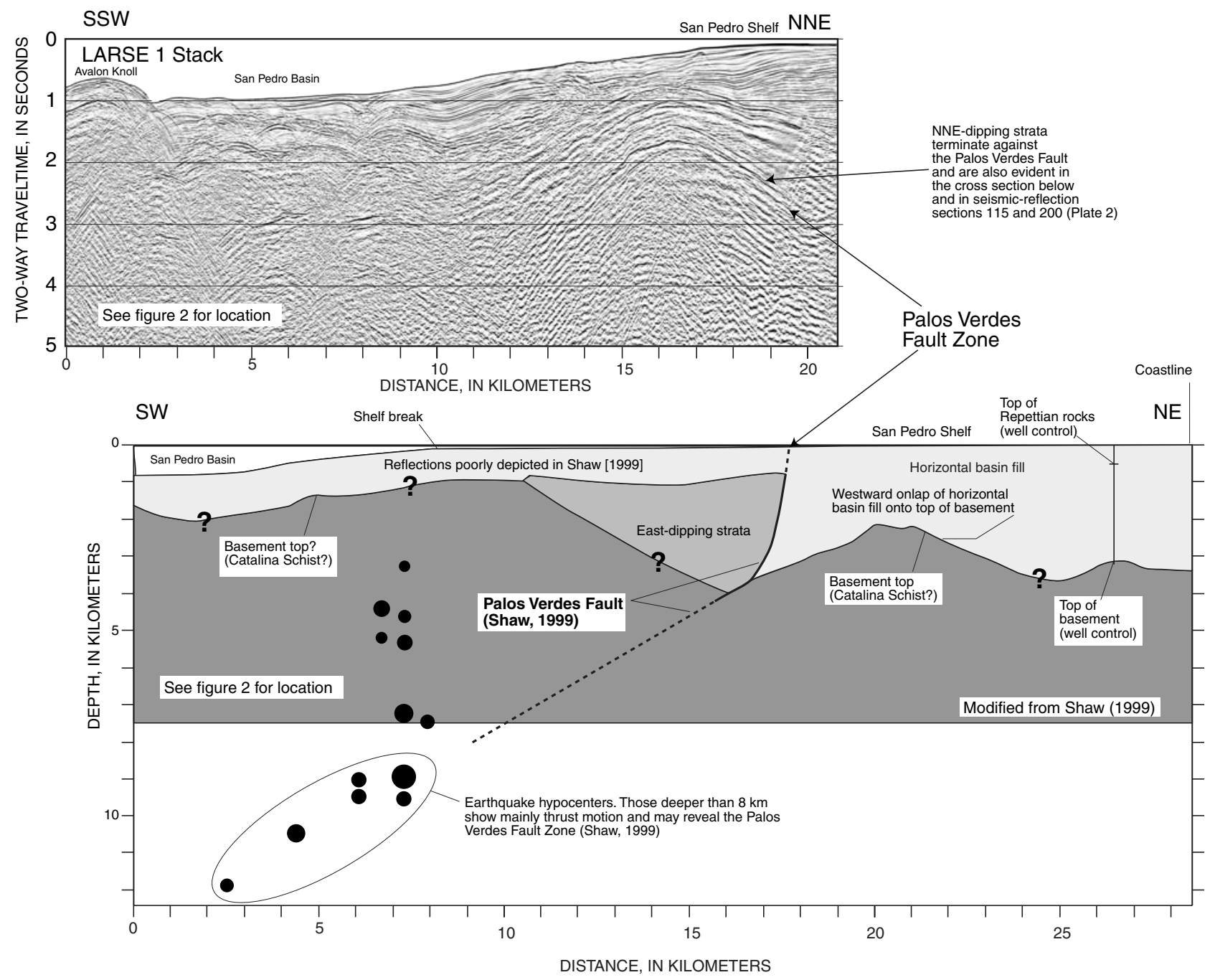

Figure 5. Top, stack of LARSE line 1 (Brocher and others, 1995), deep-crustal, seismic-reflection data obtained across the San Pedro Shelf and the Palos Verdes Fault Zone (location shown in fig. 2). These data indicate that the fault zone dips west at depth. Bottom, a simplified view of the composite cross section by Shaw (1999; location shown in fig. 3A), which shows one interpretation of the deep-crustal structure of the Palos Verdes Fault Zone. 
indicates that basement rocks below the coast southwest of the Newport-Inglewood Fault were encountered in a well at a depth of about $3 \mathrm{~km}$. Furthermore, rocks that return strong seismic reflections extend southwestward from this well, toward the Palos Verdes Fault Zone. If these reflections represent the top of basement, then basement rocks vary irregularly in depth between 2 and $3.5 \mathrm{~km}$, and adjacent to the Palos Verdes Fault Zone basement attains a depth of 3.5 $\mathrm{km}$. A cross section through the Beta oil field (figure 14 in Wright, 1991) provides the only direct information we have on basement depth southwest of the Palos Verdes Fault Zone, where a well encountered basement rocks at about $2.5 \mathrm{~km}$ depth (fig. 4).

Basement depth determined from drilling in the Beta oil field compares favorably to the depth estimated from tomographic analysis of wide-angle and refraction data collected during the LARSE experiment (ten Brink and others, 2000) (location of LARSE 1 seismic-reflection line shown in fig. 2). Assuming that rock velocities exceeding $5 \mathrm{~km} / \mathrm{s}$ indicate acoustic basement, either volcanic or metamorphic rock, then tomographic analysis of wide-angle seismic data indicates that basement northeast of the Palos Verdes Fault Zone is 2.5 to $3 \mathrm{~km}$ deep (fig. 6, top). Southwest of the Palos Verdes Fault Zone, basement is about $2.5 \mathrm{~km}$ deep and deepens to the southwest. These depths agree, to within $0.2-0.4 \mathrm{~km}$, with depths derived from oil industry operations, as described above.

\section{Previous Findings About the Main Offshore Structures}

The following discussion considers the main coastal structures in order from northeast to southwest, focusing closely on major faults that lie near the coast, especially the Newport-Inglewood, Thums-Huntington Beach, and Palos Verdes Fault Zones (fig. 1). The Newport-Inglewood rightlateral strike-slip fault has fundamental importance to the tectonic evolution of the CCB and Los Angeles Basin. Either this fault forms the contact between different basement types, or the fault closely follows this contact (Barrows, 1974; Wright, 1991, Bohannon and Geist, 1998). North and east of the fault, basement rocks consist of Jurassic and Cretaceous crystalline continental crust, whereas south and west of it the basement is Catalina Schist, which is made up of highly extended and metamorphosed subduction-zone rocks.

The Thums-Huntington Beach Fault splays southeastward away from the Palos Verdes Fault Zone (Wright, 1991) (fig. 1). Interpretive cross sections differ on fundamental issues about this fault-one shows a normal fault that dips east and is downthrown on the east (Wright, 1991), another shows that it dips west and is downthrown on the west, merging downward with the Palos Verdes Fault Zone (section 12 of Davis and Namson, 2002).

The Palos Verdes Fault Zone has been postulated to extend southwestward from the northern part of Santa Monica
Bay, to cross the bay's southeastern shoreline at the Palos Verdes Peninsula, to strike under the San Pedro Shelf, and to continue southwest of Lasuen Knoll (for example, Greene and Kennedy, 1987; Wright, 1991; Petersen and Wesnousky, 1994; Clarke and others, 1997; Marlow and others, 2000) (fig. 1). Multibeam bathymetric data show recent scarps along this fault near Lasuen Knoll (Marlow and others, 2000).

The Palos Verdes Fault Zone passes northeast of the Palos Verdes Peninsula (Woodring and others, 1946; Yerkes and others, 1965; Ward and Valensise, 1994, McNeilan and others, 1996), where the total fault-slip rate appears to be around $3 \mathrm{~mm} / \mathrm{yr}$, based on analysis of wave-cut terraces and offset stream courses (Ward and Valensisie, 1994; Stephenson and others, 1995; McNeilan and others, 1996). McNeilan and others (1996) propose that, in the recent past, the main style of movement along the Palos Verdes Fault Zone has been strike slip. Stephenson and others (1995) interpret high-resolution seismic-reflection data collected onshore to show that five strands make up the shallow part of this fault zone and that these strands dip steeply southwest and are downthrown on the northeast.

Although the Palos Verdes Fault Zone has been postulated to end far to the northwest, near the Santa Monica Mountains, no indication of a recently active part of this fault has been observed in high-resolution seismic-reflection data collected in the southern part of Santa Monica Bay (Nardin and Henyey, 1978; Fisher and others, in press). If the active part of the fault does not extend northwest of the Palos Verdes Peninsula, then slip partitioning must occur among faults neighboring the peninsula to absorb the high strain rate measured along the fault.

The geometry of the Palos Verdes Fault Zone at depth is poorly characterized. For example, Davis and Namson (2002) depict this fault zone with a steep southwestern dip (about $60^{\circ}$ ) in the upper $5 \mathrm{~km}$ of the crust. These authors indicate that, deeper than $7 \mathrm{~km}$, the fault zone dips about $25^{\circ}$ southwest. Similarly, Shaw (1999) used depth-converted seismicreflection sections to indicate that the Palos Verdes Fault Zone is steep to vertical in the upper $5 \mathrm{~km}$ of the crust, but below that depth, the fault is postulated to dip about $30^{\circ}$ southwest. Shaw and Suppe (1996) tied movement along the Palos Verdes Fault Zone to deeper movement along the Compton thrust fault, which is blind and dips northeast. In opposition to these two interpretations, cross sections by Wright (1991) show the Palos Verdes Fault Zone as a vertical or steeply east dipping strike-slip fault, at least for depths shallower than about $9 \mathrm{~km}$.

Nardin and Henyey (1978) propose that deformation of strata below the San Pedro Shelf is concentrated in zones that these authors referred to as anticlinoria. One anticlinorium deforms rocks under the Palos Verdes Peninsula, and another involves rocks that make up Lasuen Knoll, southeast of the San Pedro Shelf (fig. 1). A third anticlinorium underlies the western part of the San Pedro Shelf, along and west of the Palos Verdes Fault Zone. Formation of anticlinoria is attributed, in part, to convergent dextral shear along this fault zone. 

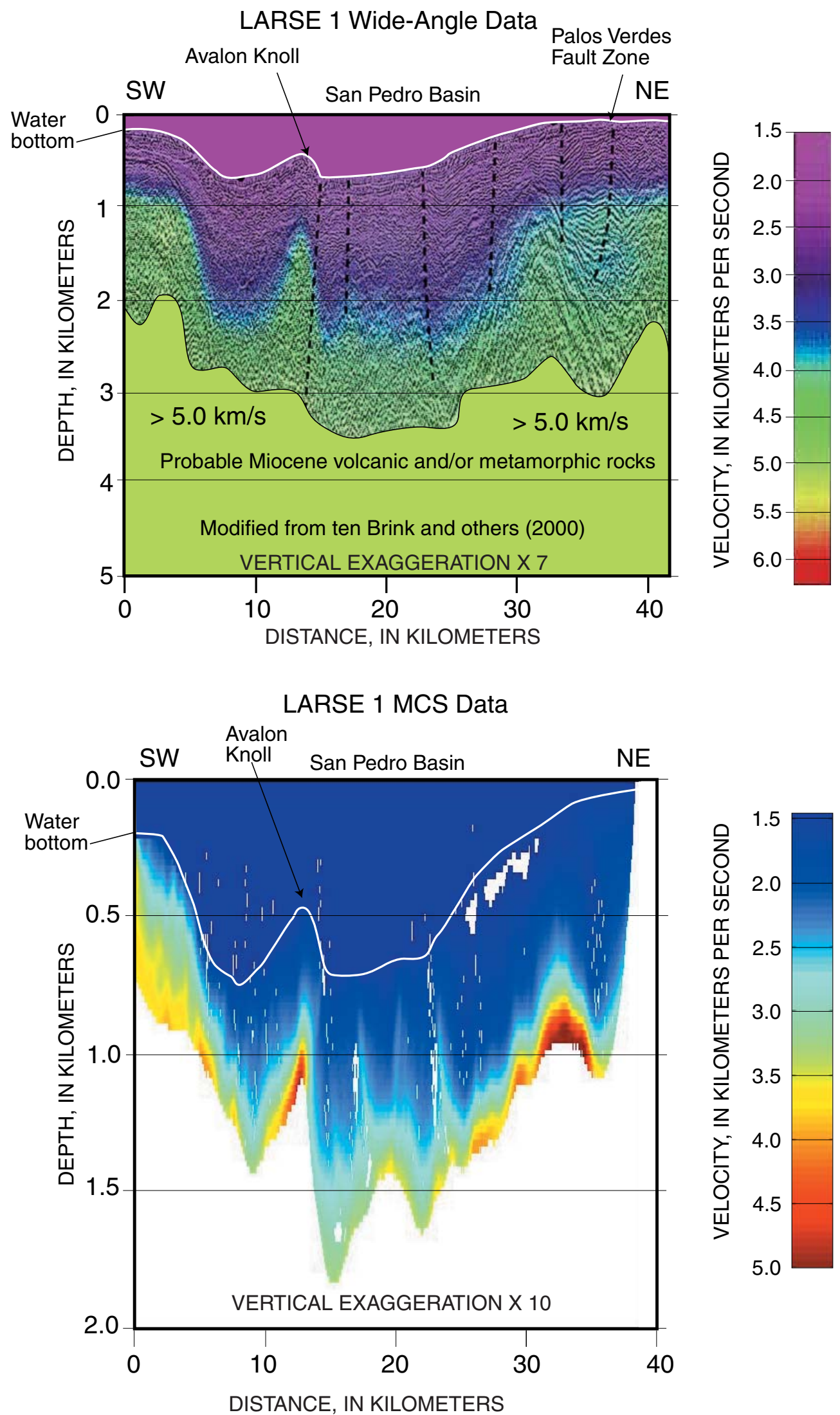

Figure 6. Tomographic velocities from wide-angle arrival times recorded during the LARSE experiment (top, after ten Brink and others, 2000) and derived from an analysis of arrivals recorded along the MCS streamer during the LARSE experiment (bottom). 


\section{Geophysical Data}

\section{Seismic-reflection Data}

Multichannel seismic (MCS) reflection data used herein (fig. 2) were collected by the U.S. Geological Survey during three cruises (Normark and others, 1999a, b; Gutmacher and others, 2000). The seismic system included a 24-channel streamer with 10 -m-long hydrophone sections. The resulting 5-m common-depth-point (CDP) interval provides high spatial resolution. The sound source was a dual-chambered generator-injector airgun; each chamber had a volume of $573 \mathrm{~cm}^{3}$ $\left(35 \mathrm{in}^{3}\right)$. The airgun was suspended from a float to maintain a constant source depth of $1 \mathrm{~m}$, and it was fired every $12 \mathrm{~s}$ with an air pressure of 3,000 psi.

Seismic-reflection data were also collected using a highresolution Huntec system that included a boomer platform towed between 6 and $160 \mathrm{~m}$ below the sea surface. The frequency spectrum of the Huntec system spanned from 0.5 to 8 $\mathrm{kHz}$ and peaked between 1.5 and $5 \mathrm{kHz}$.

Deep-crustal seismic-reflection data were collected in 1994 off Southern California for the Los Angeles Regional Seismic Experiment (LARSE; see fig. 2 for seismic line location) (Brocher and others, 1995). LARSE MCS data are 40-fold and were collected aboard the R/V Maurice Ewing. The seismic source array consisted of 20 airguns having a total chamber volume of $137.7 \mathrm{~L}\left(8,470 \mathrm{in}^{3}\right)$. The digital streamer was 4,200 m long and had 160 data channels. Results from the LARSE experiment are reported elsewhere (ten Brink and others, 2000; Fuis and others, 2001; Godfrey and others, 2002).

\section{Rock-Velocity Data}

Velocities used to convert seismic-reflection data to depth were obtained from sonic logs, a regional velocity model, and tomographic inversion of shallow arrivals in deep-crustal LARSE MCS data. Digitized sonic-log data (Suess and Shaw, 1998) (fig. 7) are from wells, located in the southeastern part of the Los Angeles Basin, that penetrated Pliocene and Quaternary sedimentary rocks. Additional velocity data from wells drilled in the Los Angeles and San Pedro Harbors show the velocity variation in the upper $300 \mathrm{~m}$ of Pleistocene and Holocene sediment (D. Ponti, written commun., 2002). These wells are located east of the Newport-Inglewood Fault Zone, which is the boundary at depth between basement rock types. These wells, therefore, were drilled into rocks that may have accumulated and compacted at different rates from the rocks in our study area. Nonetheless, we use these sonic logs to infer velocity variation within Pliocene and younger rocks and sediment down to a maximum depth of $3 \mathrm{~km}$.

An average curve drawn through the sonic-log velocity data described above differs from a summary of regional rock-velocity data (Magistrale and others, 2000) (fig. 7). Deeper than $1 \mathrm{~km}$, velocities from the regional compilation are substantially higher than the spread of values derived from sonic logs.

Other velocity values are derived from tomographic inversion of seismic-reflection data collected along the MCS streamer during the LARSE experiment in 1994 (fig. 6, bottom). These velocities are important because they are the only detailed information we have on the velocity of sound in rocks southwest of the Palos Verdes Fault Zone. When calculating tomographic velocities, we edited LARSE seismic data to remove low-quality recording channels and bad shots, and the first arrivals were picked for every shot to within $8 \mathrm{~ms}$. First-arrival traveltimes numbered nearly 180,000, and all were entered into an iterative, two-dimensional tomographic inversion algorithm that is based on a finite-difference solution to the eikonal equation (Aldridge and Oldenburg, 1993). The vertical and horizontal spacing of the grid of velocity values was $12.5 \mathrm{~m}$. In general, velocities for given depths obtained from tomographic analysis of LARSE data are higher than either the average derived from sonic logs or the regional curve of Magistrale and others (2000) (fig. 7). The higher velocities result mainly from the shallow depth of Miocene rocks southwest of the Palos Verdes Fault Zone.

\section{Potential-Field Data}

Offshore aeromagnetic data were obtained during a regional survey (Langenheim and others, 1993) flown along flightlines spaced $1.6 \mathrm{~km}$ apart. A magnetic high is located over the western San Pedro Shelf, where seismic lines 115 and 200 intersect (fig. 8, top). To help delineate the outline of the magnetic source body (shown as a dashed line in both parts of fig. 8), a computer algorithm was used to locate the maximum horizontal gradient of the magnetic field.

Offshore gravity values (fig. 8, bottom) are from a 3-km grid of gravity measurements derived from scattered field data collected by the National Oceanic and Atmospheric Administration and the U.S. Geological Survey and reduced to isostatic gravity values. These gravity data are accurate to a few mGal, so they are suitable for regional but not detailed studies. These data reveal mainly density variations within the middle and upper crust.

\section{Offshore Structure from Seismic-Reflection Data}

For the purposes of discussion, the study area is divided into two structural belts, separated by the Palos Verdes Fault Zone, that extend southeastward along the western fringe of the Los Angeles Basin. The eastern belt includes the Wilmington Graben (Fischer and others, 1987), an elongate, nearshore basin confined between the Newport-Inglewood and Palos Verdes Fault Zones (fig. 1). (The term "Wilmington Graben" is somewhat misleading because the feature is bounded by 
strike-slip, not normal, faults. Even so, the name "Wilmington Graben" is used here because of its precedence in the literature and common usage.) The western structural belt includes variably deformed rocks that lie west of the Palos Verdes Fault Zone, mainly rocks under the western San Pedro Shelf and slope, as well as rocks and sediment filling the deep-water San Pedro Basin. These structural belts are discussed in order from northeast to southwest.

\section{Structural Belt East of the Palos Verdes Fault Zone: The Wilmington Graben}

The Newport-Inglewood and Palos Verdes Fault Zones bound the Wilmington Graben on the northeast and southwest, respectively, and the Thums-Huntington Beach Fault deforms rocks within the graben (fig. 9). Unfortunately, owing to environmental restrictions placed on seismic surveys off Califor-

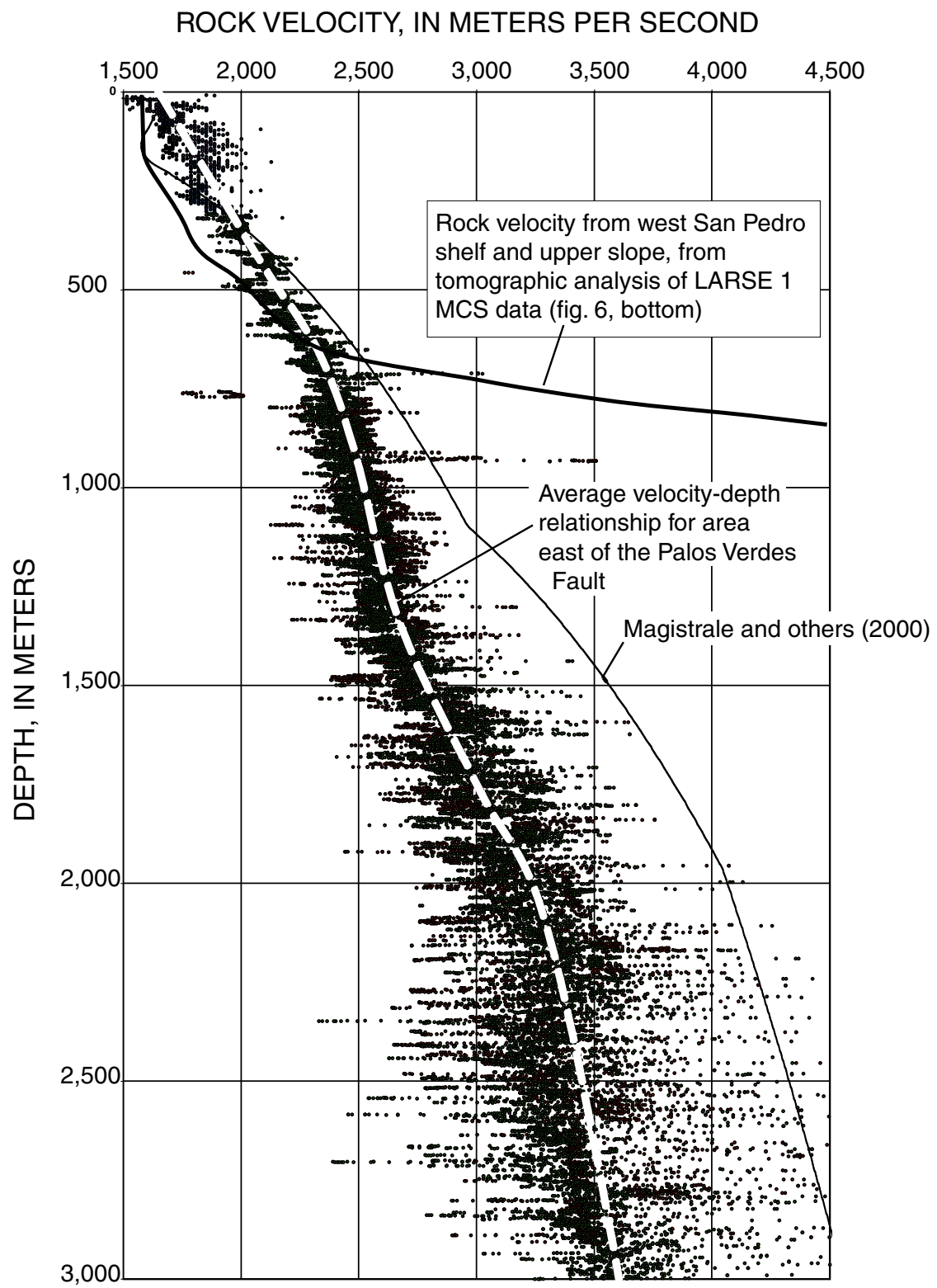

Figure 7. Velocity-depth function derived from digitized sonic logs from five wells and averaged (Suess and Shaw, 1998; D. Ponti, written commun., 2002). This velocity-depth function was used to convert time to depth for seismic-reflection data collected east of the Palos Verdes Fault Zone, over the Wilmington Graben, and under deep-water areas. Rock velocities from depths $>300 \mathrm{~m}$ are from sonic logs from the Tidewater Oil Hellman Estates \#1 and the Amerada Hess Lakewood Community \#1 wells (see fig. 3 for locations). The thick solid line shows the velocity distribution derived from tomographic analysis of LARSE MCS data from near the shelf break. These higher velocities from near the shelf break reflect the shallow depth of Miocene rocks. 


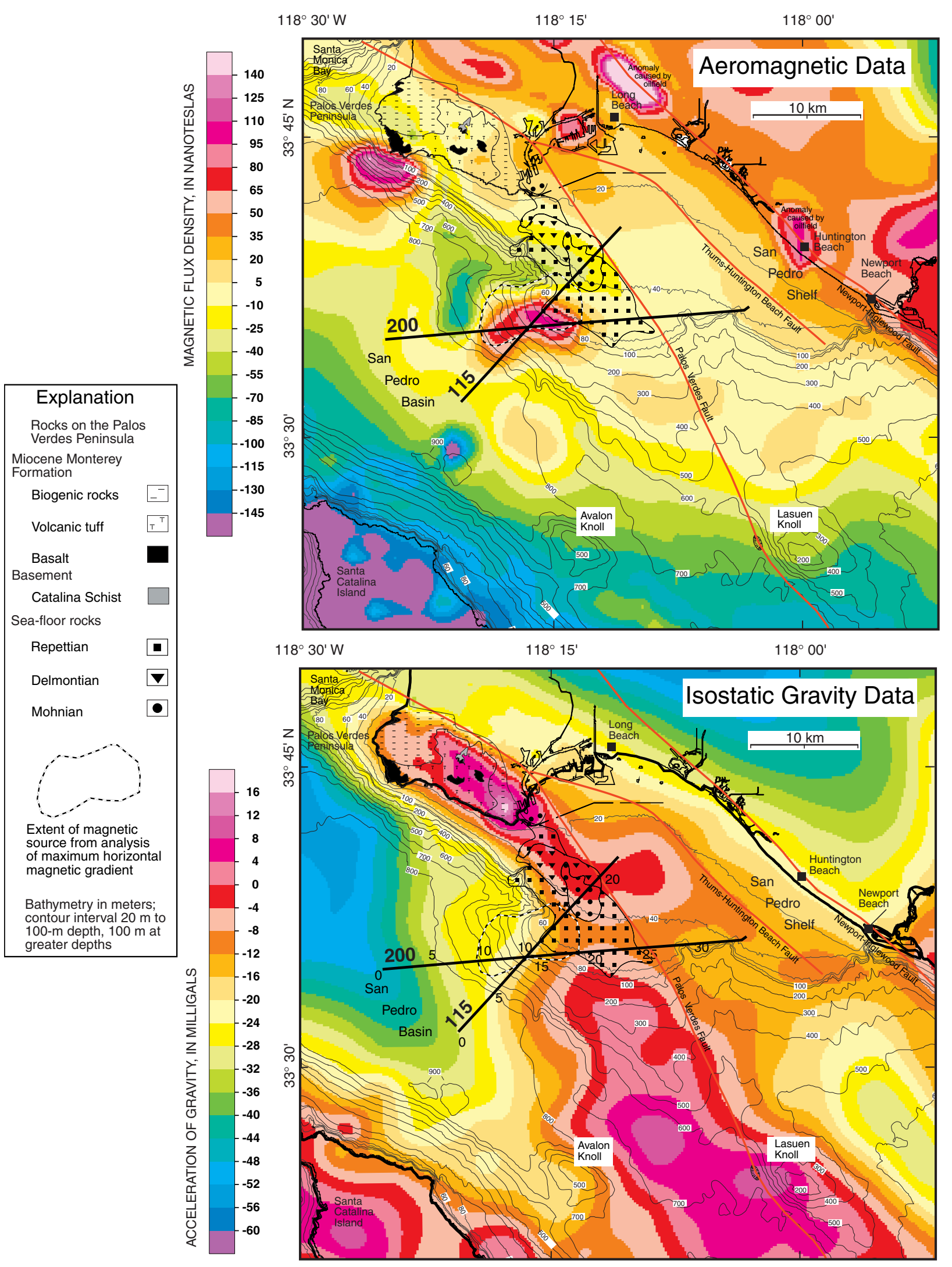

Figure 8. Aeromagnetic anomaly map (top) and isostatic gravity map (bottom) of the study area. An aeromagnetic anomaly near the northwest corner of the Palos Verdes Peninsula lies near an onshore basalt outcrop. Gravity and magnetic models along seismic-reflection lines 200 and 115 are shown in figure 24. Seismic-reflection sections are shown in plate 2. Ages of sea-floor rocks are from Nardin and Henyey (1978). Onshore geology is from Woodring and others (1946). 
nia, none of the seismic-reflection lines shown here crosses the Thums-Huntington Beach Fault. However, geologic sections published elsewhere show this fault's structure (see section locations in fig. 3A). For example, Wright (1991) shows that the northeast side of this fault dropped down, forming the large Wilmington Anticline. Basement rocks below the graben are at depths between 2 and $3 \mathrm{~km}$ (fig. 5).

Rocks within the Wilmington Graben are only mildly deformed, except in the far western part of the graben, directly adjacent to the Palos Verdes Fault Zone (fig. 10, location shown in fig. 9). Seismic-reflection data indicate that very shallow strata within the graben are subhorizontal and overlie a shallow unconformity at a traveltime of about $0.2 \mathrm{~s}$, but this relationship is largely obscured by water-bottom multiples. This unconformity truncates the tops of underlying beds that have an apparent southwest dip. The unconformity and the uppermost part of the section in the Wilmington Graben cross the Palos Verdes Fault Zone and are deformed by it, indicating relatively recent fault movement.

Down to a traveltime of about $0.8 \mathrm{~s}$ (about 800-m depth), a deltaic sequence progrades across the graben in an apparent southwestward direction. A reverse fault within the graben, on figure 10, below shotpoint (SP) 1500, offsets this unconformity but does not extend far upward through the overlying rocks. A third unconformity is evident on the right half of figure 10, at a traveltime of $1.5 \mathrm{~s}$.

In the southeastern part of the study area, east of Lasuen Knoll, the Newport-Inglewood Fault and the Palos Verdes Fault Zone diverge, and the widening deep-water area between these faults has received extensive turbidite fill from channels that make up the Newport Canyon. Rock or coarse-grained sediment that produces strong reflections are at shallow depth (fig. 11, top). For example, below the northeast end of seismicreflection line 76, little-deformed basin fill is only about 500 $\mathrm{m}(0.4 \mathrm{~s})$ thick over flat, strongly reflective rocks. These rocks extend southwestward to an inflection point, where the rocks abruptly dip more steeply southwest into the basin. The appearance of the reflections below the very flat and distinct reflection on seismic section 76 is consistent with the interpretation that the distinct reflection marks the contact between turbidite sediment, perhaps of latest Pleistocene age, and underlying, more consolidated rock. Discontinuous reflections extend to traveltimes at least as great as $2.5 \mathrm{~s}$ (nearly $2 \mathrm{~km}$ below sea level), suggesting that the basin deepens sharply southwest of the inflection. The upper part of the basin fill is subhorizontal.

Seismic section 74 (fig. 11, bottom; location shown in fig. 9) shows a flat, strong reflection under the western area of the basin. At an inflection point below SP 600, this strong reflec-

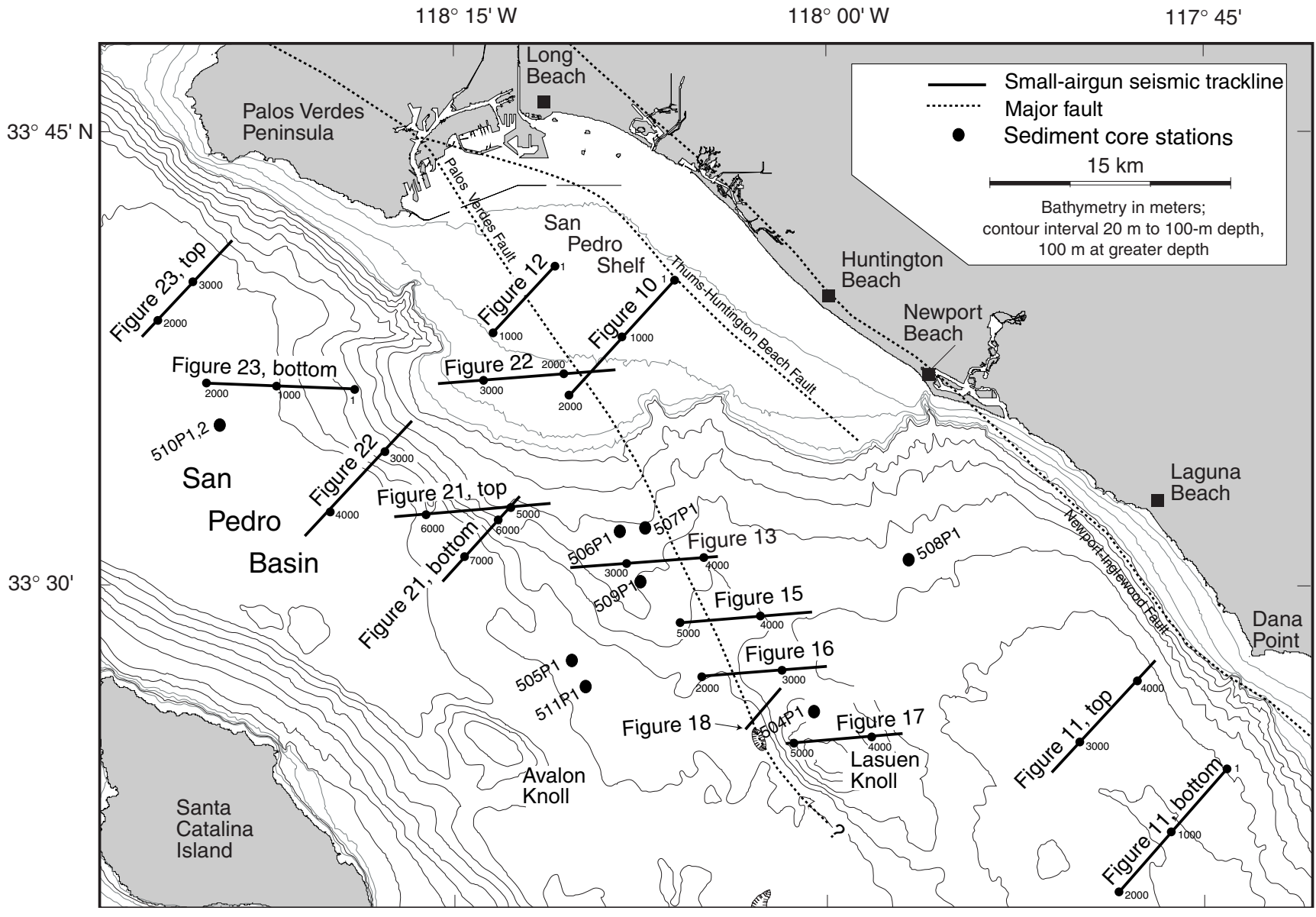

Figure 9. Index map of detailed seismic sections over selected features below the San Pedro Shelf and Lasuen Knoll. Small numbers indicate shot points along seismic lines. Dots with alphanumeric indicators show sediment core locations. 


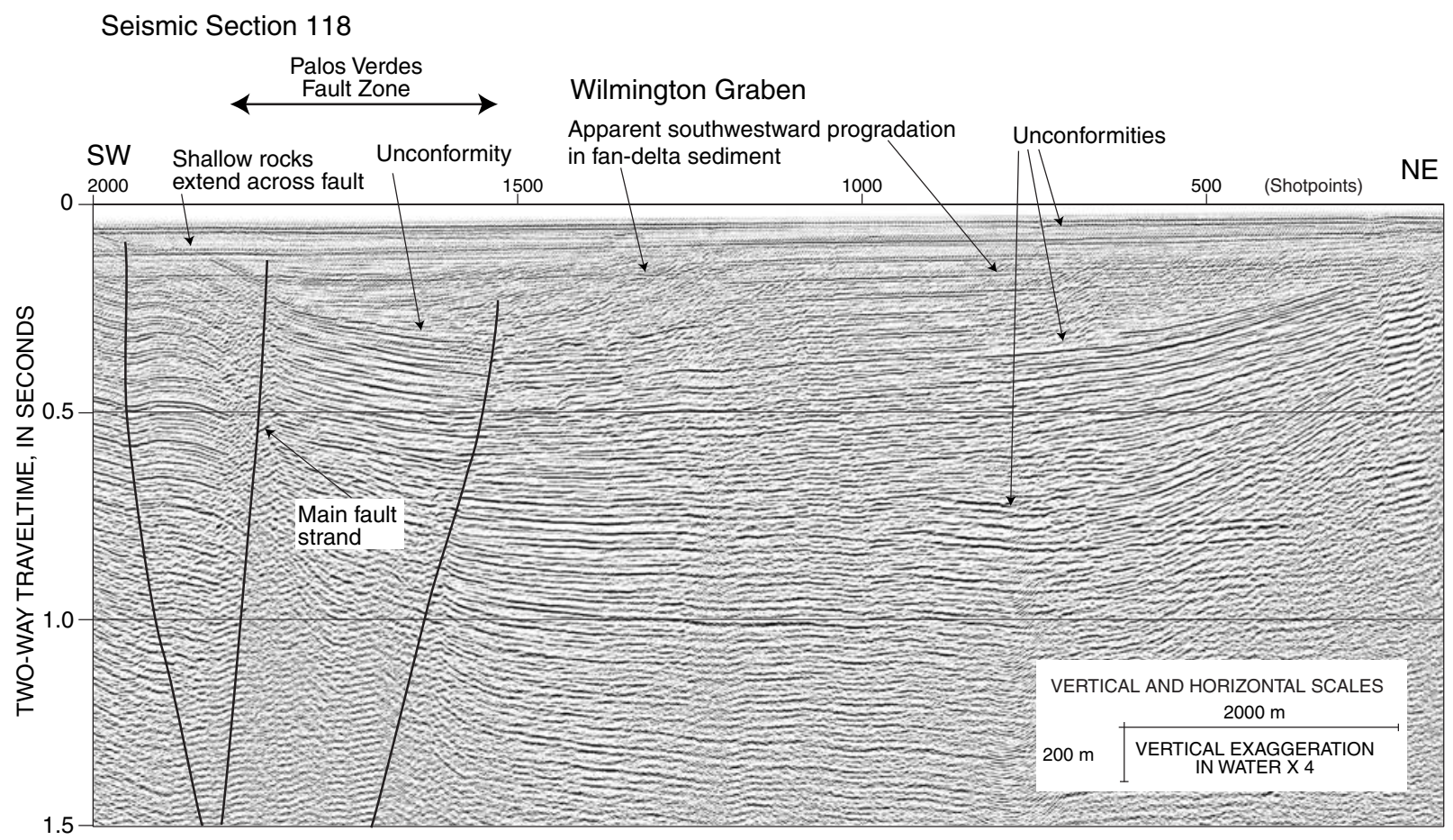

Figure 10. Seismic section over the Palos Verdes Fault Zone and Wilmington Graben under the San Pedro Shelf. Section location is shown in figure 9 .

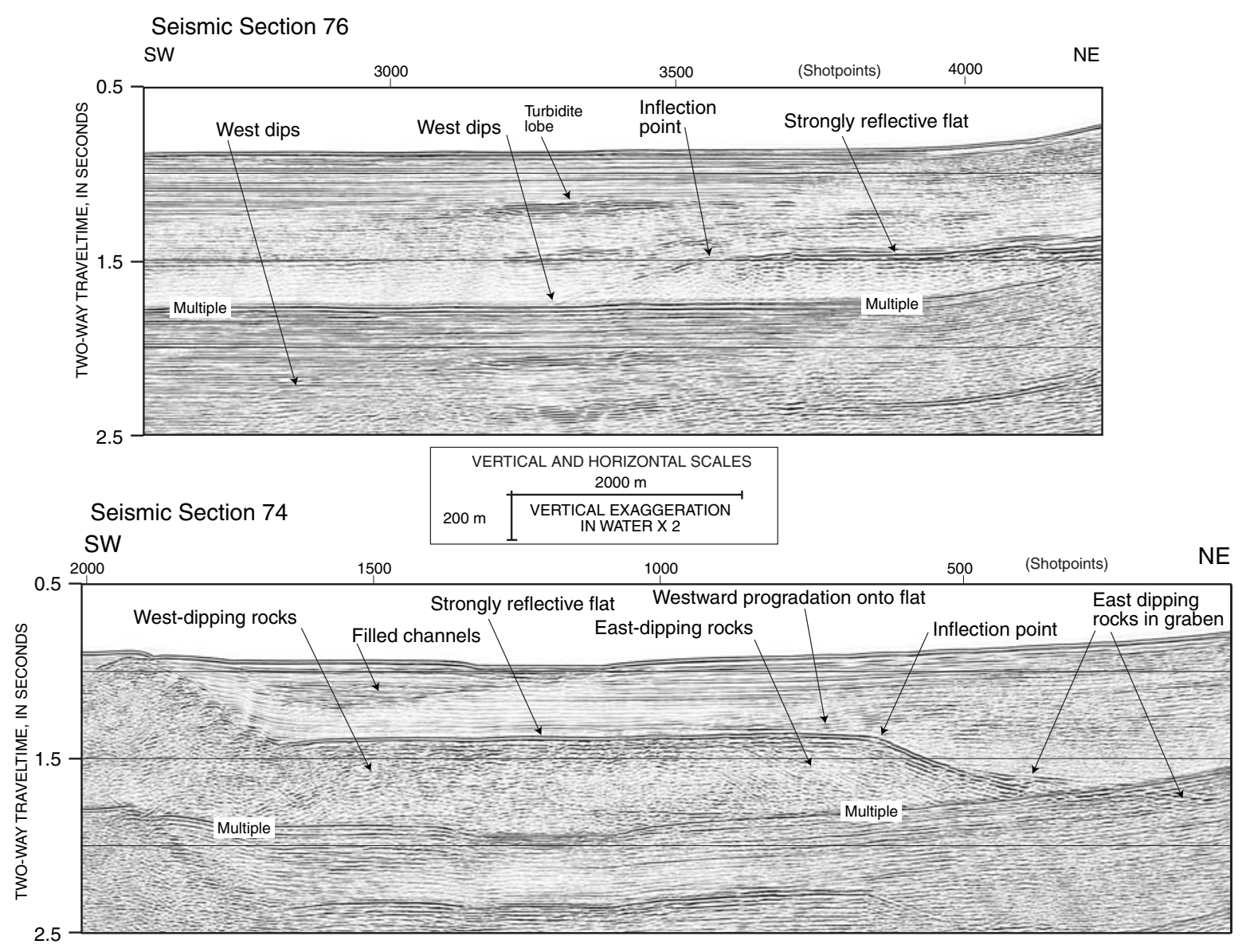

Figure 11. Seismic sections showing the geologic structure near Dana Point. Section locations are shown in figure 9. 
tion begins an eastward descent into the deep part of the basin. Rocks below the strong reflection return coherent reflections. Below SP 1500 on seismic section 74, reflections from below the strong one dip primarily west, whereas below SP 800, other deep reflections dip east. Because of these deep reflections, the strong, flat reflection is unlikely to be from the top of metamorphic basement; instead the strong reflection is more likely to be from an unconformity cut across sedimentary rocks. The opposing dips of these rocks outline a truncated anticline. The strong reflection may be from a wave-cut terrace cut along the top of deformed Miocene sedimentary rocks. Deep-basin deposits below SP 500 on section 74 have moderate apparent dip to the east, and shallower parts of the basin fill prograde in the opposite direction, southwestward across the flat strong reflector.

\section{Structural Variation Along the Palos Verdes Fault Zone}

The Palos Verdes Fault Zone is the most prominent and arguably the most complicated structure revealed by the seismic-reflection data. It bounds folded shelf rocks, primarily of Miocene and Pliocene age, to the west (Nardin and Henyey, 1978), whereas a thick (typically $1 \mathrm{~km}$ ) section of mainly flatlying upper Pliocene and Quaternary rocks and sediment abuts the fault on the east (fig. 4).
Cross sections (Wright, 1991; Davis and Namson, 2002) derived primarily from oil-industry seismic-reflection data (locations shown in fig. 3A) indicate that at shallow depth $(<$ $1 \mathrm{~km}$ ) under the San Pedro Shelf the Palos Verdes Fault Zone is nearly vertical, but that it curves downward to dip steeply west. This geometry is also evident in a stack of multichannel seismic-reflection data obtained along LARSE line 1 (fig. 5, top). Furthermore, a summary diagram made from industry seismic-reflection data (Shaw, 1999; fig. 5, bottom) shows not only that this fault zone dips west but also that rocks below about $1 \mathrm{~km}$ depth along the west side of the fault dip east and terminate against the fault plane.

Some elements of the fault structure just described are also evident in migrated time sections of small-airgun seismicreflection data. These sections reveal that at shallow depth $(<$ $1 \mathrm{~km}$ ) under the northern San Pedro Shelf, the Palos Verdes Fault Zone dips steeply west or is vertical (see, for example, pl. 1, seismic-reflection sections 115 and 118). A more detailed rendition of seismic-reflection section 115 (fig. 12) shows that this fault zone is composed of at least three fault strands that are nearly vertical to traveltimes less than about $1 \mathrm{~s}$. This section also shows that shallow strata from within the Wilmington Graben extend westward through the Palos Verdes Fault Zone, are offset by the fault strands, and appear to unconformably overlie Miocene and Pliocene rocks on the fault's west side.

Structures along and within the Palos Verdes Fault Zone reveal that the intensity of compressional deformation

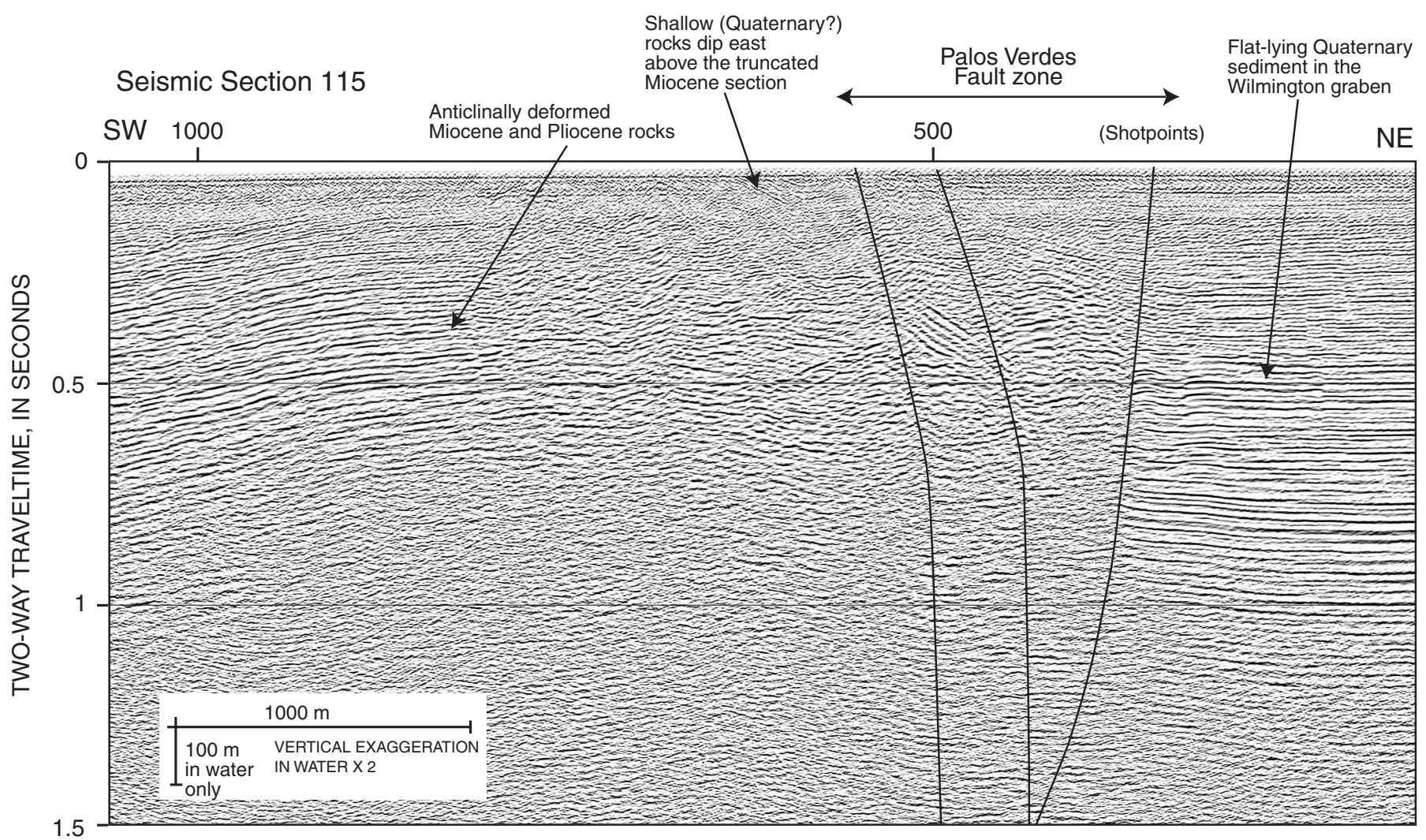

Figure 12. Detailed seismic section over the Palos Verdes Fault Zone, showing that this zone includes several fault strands and offsets shallow rocks. Section location is shown in figure 9. 
decreases southeastward across the San Pedro Shelf. In particular, the anticline along the west side of the fault zone (pl. 1, seismic section 115) decreases in structural relief and broadens southeastward (pl. 1, seismic section 118). Southeast of the shelf, below the upper part of the slope, this anticline appears to die out entirely, as little trace of it appears on seismic section 84 (pl. 1). In fact, this seismic section shows that the faults along the projected location of the Palos Verdes Fault Zone all exhibit normal separation. Such faults are even more readily evident on seismic-reflection section 66 (pl. 1 and fig. 13A), where the main normal fault dips east.

The main strands of the Palos Verdes Fault Zone have moved recently, as shown by high-resolution Huntec seismicreflection data. These strands exhibit normal separation, down on the east, and they offset or warp the sea floor (seismic section 66 on pl. 1, figs. $13 A, B$ ). Huntec seismic-reflection data reveal an angular discordance within sediment west of the main fault strands (fig. 13B). Parallel-bedded rocks underlying this discordance can be tentatively correlated with parallel-bedded sediment across the fault. No stratigraphic ages exist for this sediment, but were they available, they would give the onset time for the most recent phase of fault movement. Another small normal fault, down on the west, within the Palos Verdes Fault Zone emerges within a sea-floor depression, indicating recent fault movement and possible fluid flow (fig. 13C).

A bathymetric saddle, where the sea floor attains a depth as great as $500 \mathrm{~m}$, separates the southeastern edge of the San
Pedro Shelf from the high-standing Lasuen Knoll (bathymetry shown in fig. 1 and the index map on pl. 1). Oblique projections of multibeam bathymetric data obtained over the San Pedro Shelf and slope (figs. 14A, B) show the incised head of the San Gabriel Canyon at the southeastern edge of the San Pedro Shelf. This channel head is located where underlying rocks are deformed by normal faults that make up the Palos Verdes Fault Zone, suggesting that the extensional deformation helped determine the course of the channel's upper reach. The San Gabriel Canyon crosses the Palos Verdes Fault Zone at a highly oblique angle, and its channel is not obviously deflected, either horizontally or vertically. The channel, however, does bifurcate near this crossing. One channel branch extends southeastward along the west scarp of the Lasuen Knoll, which lies along the Palos Verdes Fault Zone (Marlow and others, 2000). The other channel branch veers southwest across the floor of the San Pedro Basin. Numerous arcuate sea-floor scars along the San Gabriel channel over the lower slope might be channel meanders or slump scars.

The bathymetric saddle marks an important structural transition along the Palos Verdes Fault Zone, because southeastward through the saddle both the dip and the vergence direction of the fault zone change. The sequence of seismic sections 67, 81, and 80 (pl. 1) shows that near Lasuen Knoll this fault zone exhibits reverse separation and dips east, which is opposite to the west dip of the fault under the northern San

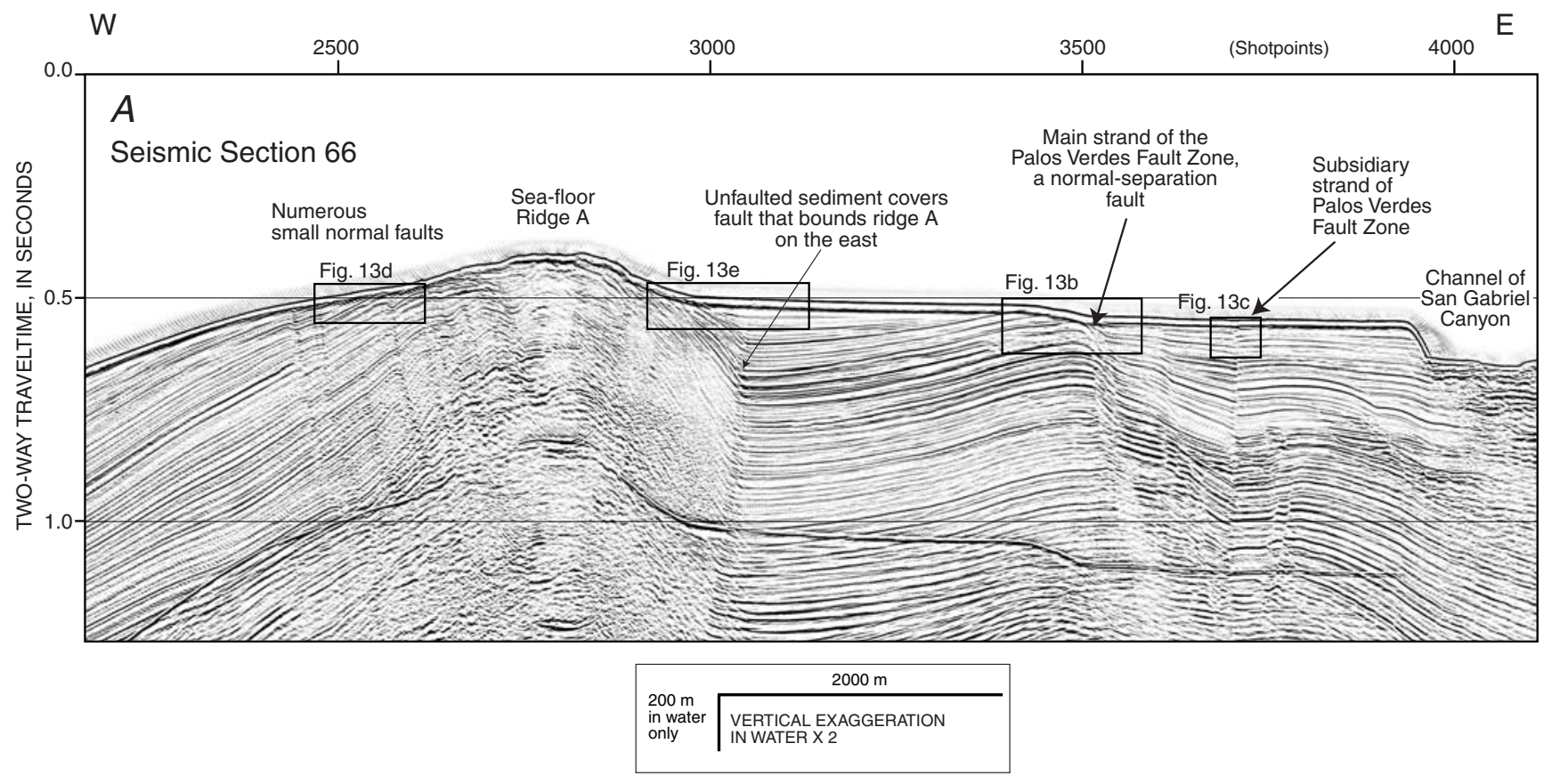

Figure 13. Detailed seismic sections over the Palos Verdes Fault Zone showing recent activity along some fault strands. Location of section 66 shown in figure 9. A, Small-airgun section over sea-floor ridge $\mathrm{A}$ and the Palos Verdes Fault Zone, where this comprises several normal-separation faults. $B$, Huntec seismic-reflection section over the main, normal-separation fault strands that make up the Palos Verdes Fault Zone. These faults offset the sea floor. $C$, Huntec seismic-reflection section showing a depression in the sea floor over a strand of the Palos Verdes Fault Zone. Fluids might escape along this fault strand. $D$, Huntec seismic-reflection section showing small normal faults that offset strata making up the west flank of ridge A. These faults offset shallow sediment but not the sea floor. $E$, Huntec seismic-reflection section shows that a sharp angular discordance separates sediment bodies that cover the fault bounding ridge $A$ on the east. This discordance is overlain by shallow strata that are essentially flat, indicating that vertical movement on the east bounding fault has ceased. 
Pedro Shelf. This east dip is apparent on seismic section 67, so the dip change of the Palos Verdes Fault Zone occurs under the bathymetric saddle and possibly under the zone of normal faults described above.

Seismic section 66 (pl. 1) shows that rocks within the Wilmington Graben flex upward along a short-radius fold that clearly does not include shallow faulting. However, faulting becomes progressively more apparent southeastward along the east boundary of the dipping rocks. For example, kink bands clearly evident on seismic section 67 (pl. 1 and fig. 15, below SP's 4000 and 4300) reveal topography on the plane of an underlying, east-dipping thrust fault, which we interpret to be the Palos Verdes Fault Zone, that lies below the depth of penetration of our seismic-reflection data.

Clear faulting along the east flank of the dipping rock section is shown below SP 1500 on seismic section 80 (pl. 1), where the dip change occurs along a west-dipping reverse fault that offsets very shallow sediment and perhaps the sea floor. The increased intensity of faulting along this zone to the southeast mirrors the heightened bathymetric expression of Lasuen Knoll.

A shallow unconformity that truncates east-dipping rocks in the Wilmington Graben (fig. 15) crosses the Palos Verdes
Fault Zone. Strongly but irregularly reflective strata reveal coarse deposits, probably channel-fill and (or) lobe deposits, within the San Gabriel turbidite system that overlies this unconformity. Complex reflections from these deposits foiled our attempt to determine whether or not the unconformity extends unbroken across the Palos Verdes Fault Zone. However, between SP's 4000 and 4200 on figure 15, rocks under the unconformity are parallel bedded and dip east, whereas strata above the unconformity are parallel bedded and flat lying. These relationships suggest that along the Palos Verdes Fault Zone near the north part of Lasuen Knoll, eastward tilting ended before the erosion that cut the unconformity. Significantly, tilting has not resumed since the erosion, because the turbidite channels of the San Gabriel Canyon have not been shifted away from what was once the locus of uplift and tilting (fig. 15). The vertical component of deformation ended before the cutting of the unconformity and the later establishment of the modern turbidite system.

A somewhat different picture of the deformation history is revealed by seismic section 68 (fig. 16), which crosses the Palos Verdes Fault Zone close to Lausen Knoll (location shown in fig. 9). This seismic section shows a sharp sea-floor
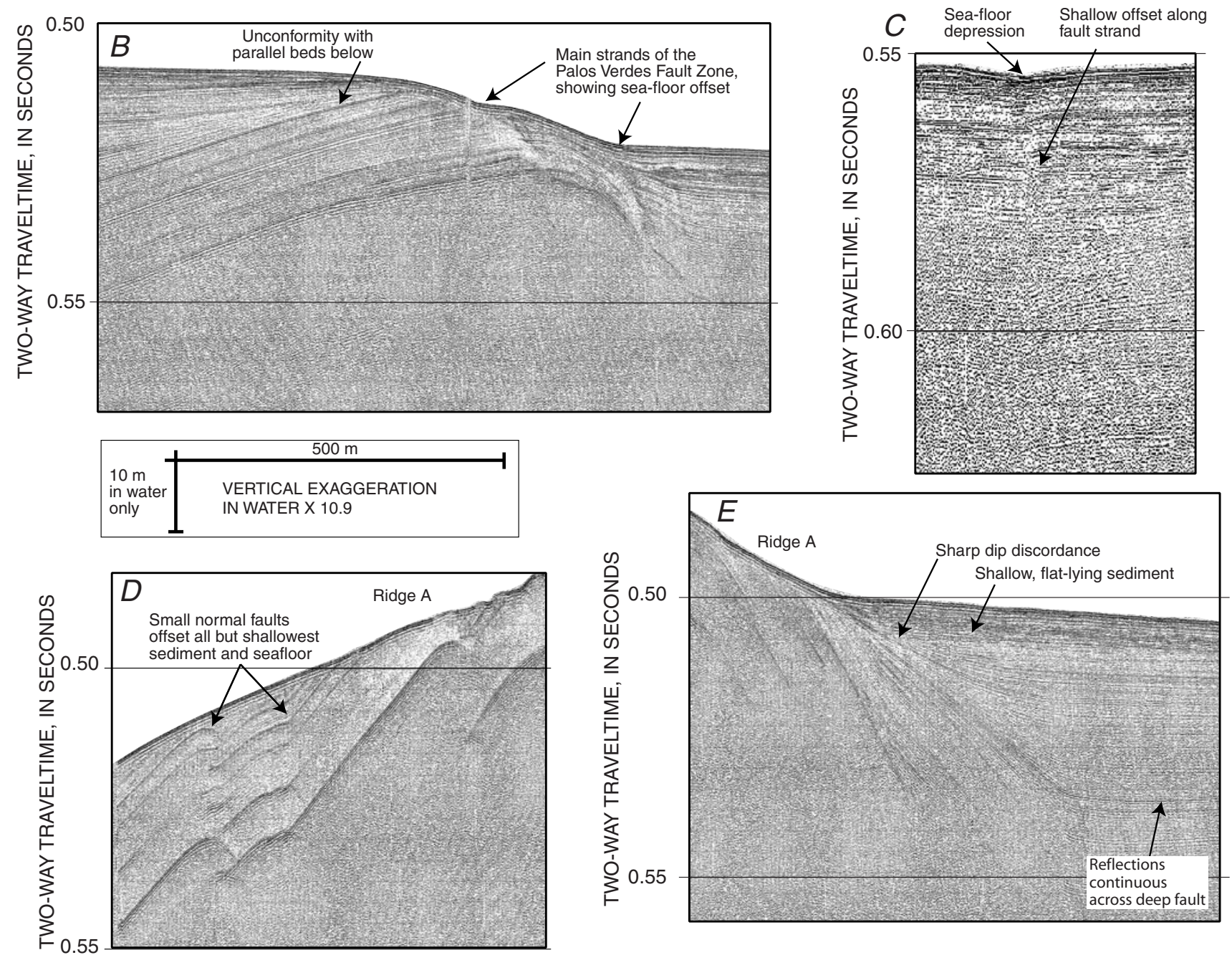

Figure 13-Continued. 

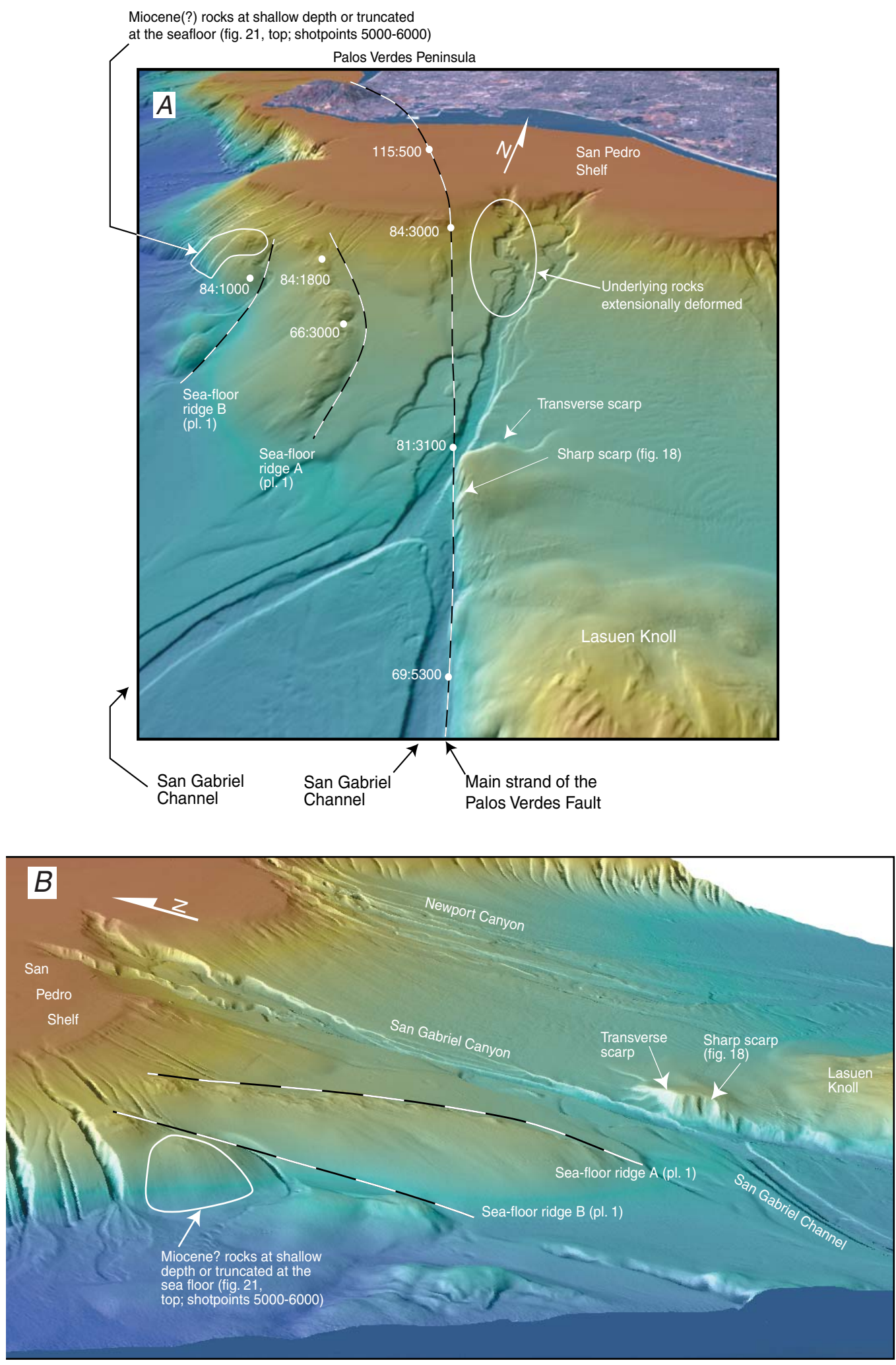

Figure 14. Oblique shaded-relief diagrams derived from multibeam bathymetric data (Gardner and Dartnell, 2002). A, Looking northwest across Lasuen Knoll and the San Pedro Shelf. Numbers give locations; for example, 84:1800 refers to seismic section 84, shot point 1800 on seismic sections in plate 1. Dashed lines show interpreted faults and sea-floor ridges A and B. B, Looking east, parallel to the continental slope that bounds the San Pedro Shelf. The transverse scarp and sharp scarp that demark Lasuen Knoll have sharp corners and edges, indicating recent movement along what are probably underlying faults. 


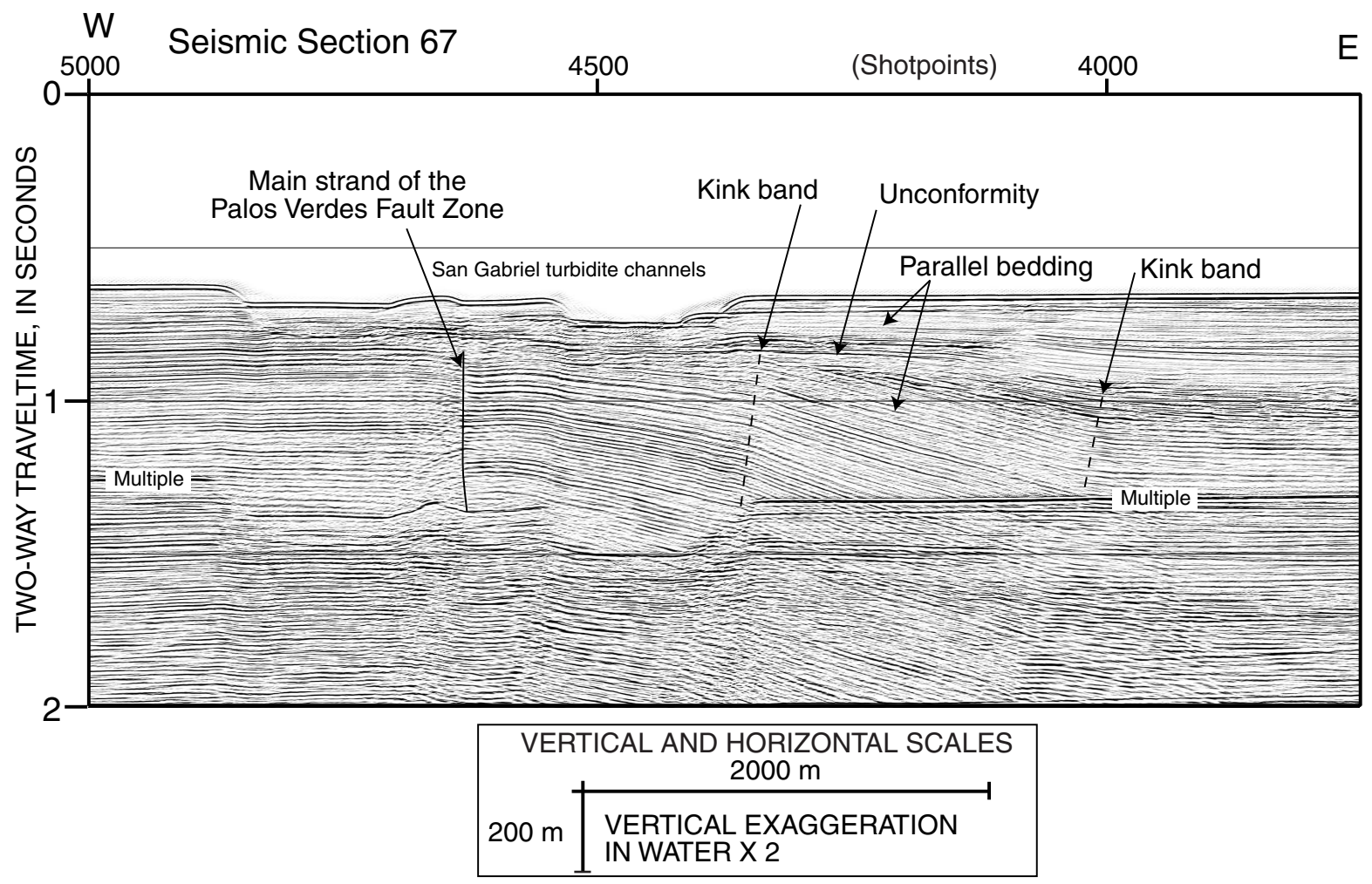

Figure 15. Detailed seismic section over the Palos Verdes Fault Zone under the bathymetric saddle between the San Pedro Shelf and Lasuen Knoll. Section location is shown in figure 9. Recent vertical movement along the main fault strand seems to have been small, because the San Gabriel Canyon cuts into the fault's upper plate.

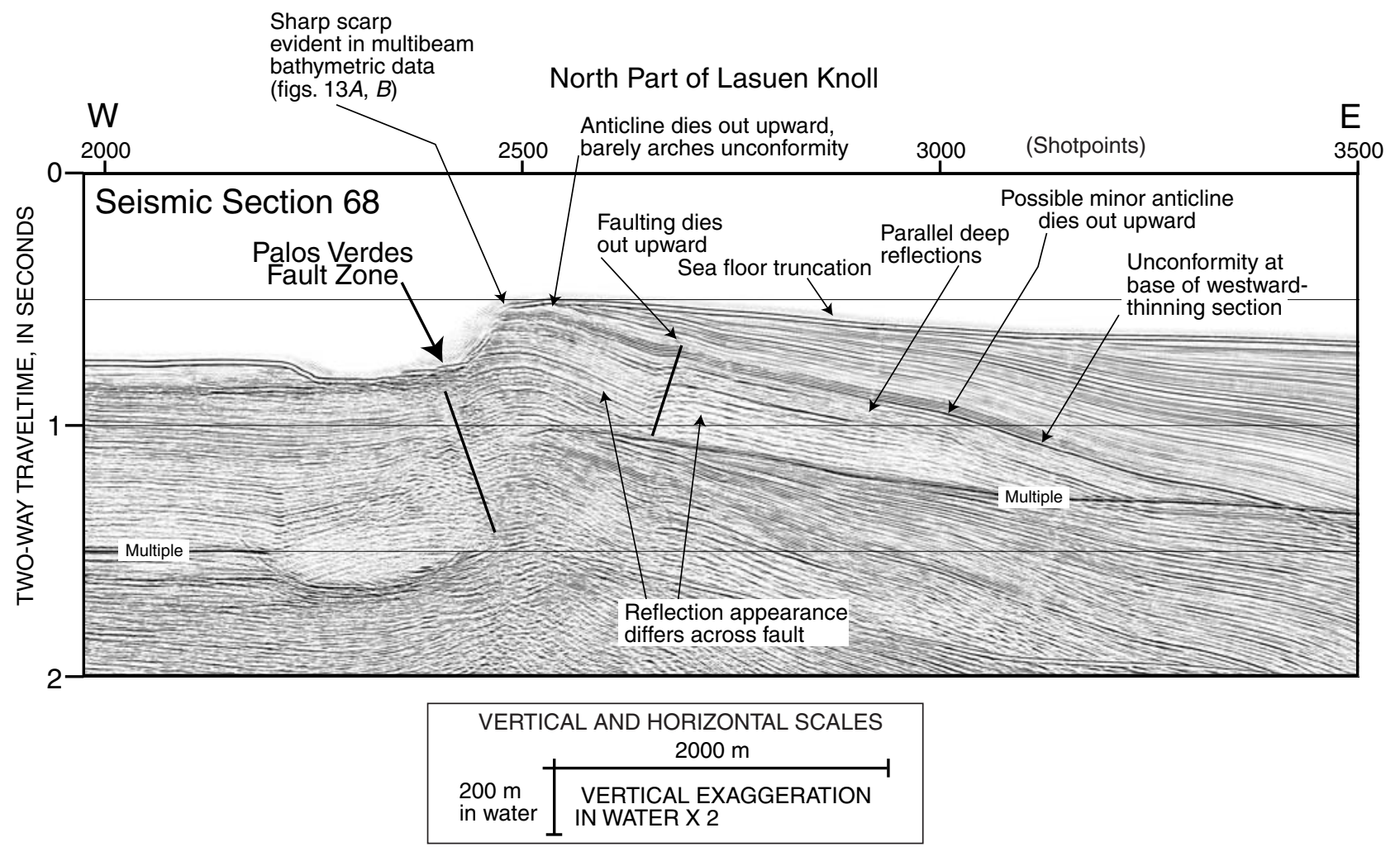

Figure 16. Detailed seismic section over the Palos Verdes Fault Zone and Lasuen Knoll, showing the stratigraphy and structure of the sharp scarp (see also fig. 14). Section location is shown in figure 9. 
scarp that is perched above and west of an anticline and an east-dipping fault below SP 2500. These structures lie along the Palos Verdes Fault Zone, and following Marlow and others (2000) we propose that they are the southeastward extension of this fault zone along the west flank of Lasuen Knoll. The sea-floor scarp, probably caused by vertical uplift along the Palos Verdes Fault Zone (fig. 16), is clearly evident in the oblique views of multibeam bathymetric data (figs. 14A, $B$, labeled "sharp scarp"). This scarp has sharp edges that contrast strongly with the rounded contours of the sea floor elsewhere. On this basis, the scarp appears to be young and indicates recent movement along the Palos Verdes Fault Zone. Taken together, seismic-reflection and multibeam bathymetric data show that this fault zone near Lasuen Knoll exhibits reverse separation and dips east.

An unconformity (indicated by an arrow below SP 3200 on fig. 16) separates rocks below, which have nearly constant thickness, from sediments above, which thin markedly westward. Sediments just above the unconformity thin gradually westward, whereas beds higher up in the section thin more rapidly. The geometry of these strata indicates that broad eastward tilting of the upper plate of the Palos Verdes Fault Zone began shortly after the unconformity formed and was buried.

An anticline underlies the sea-floor scarp along the east side of the Palos Verdes Fault Zone (fig. 16, below SP 2500). This anticline dies out upward through the rock section, so that shallow rocks are barely arched. Likewise, a minor fault east of the anticline, below SP 2700, offsets deep basin rocks and extends upward through the unconformity but dies out just above the unconformity. An apparent minor anticline below SP 3000 also dies out upward. All of these structures indicate a decreasing intensity of local folding and faulting through time along the Palos Verdes Fault Zone near the Lasuen Knoll.

East-dipping rocks under the crest of Lasuen Knoll are truncated at the sea floor. This truncation may have occurred subaerially, as suggested by a modified version of seismic section 69 (fig. 17). To make this figure, the seismic section was rotated $3^{\circ}$ counter-clockwise so that discontinuous, flat parts of the knoll's crest, as well as notches in the sea floor, could be connected by dashed horizontal lines. We propose that these lines connect wave-cut platforms and terraces. This interpretation is bolstered by the recovery of shallow benthic fauna from deep water along the knoll flank. A piston core sample obtained from 373-m water depth on Lasuen Knoll about 5 km north of the seismic section in figure 17 contains a shelf-edge benthic fauna (Mary McGann, written commun., 2003). This finding is consistent with the proposed terraces having been cut at sea level. The youth of the tilting derived here agrees with the point made above about the youth of the tilting of rocks along the west side of the Wilmington Graben.

A point worth noting is that the sharpness of the sea-floor scarp (figs. 14 and 16) indicates that the Palos Verdes Fault Zone was reactivated recently and is most likely responsible for the eastward tilting of rocks in the Wilmington Graben and

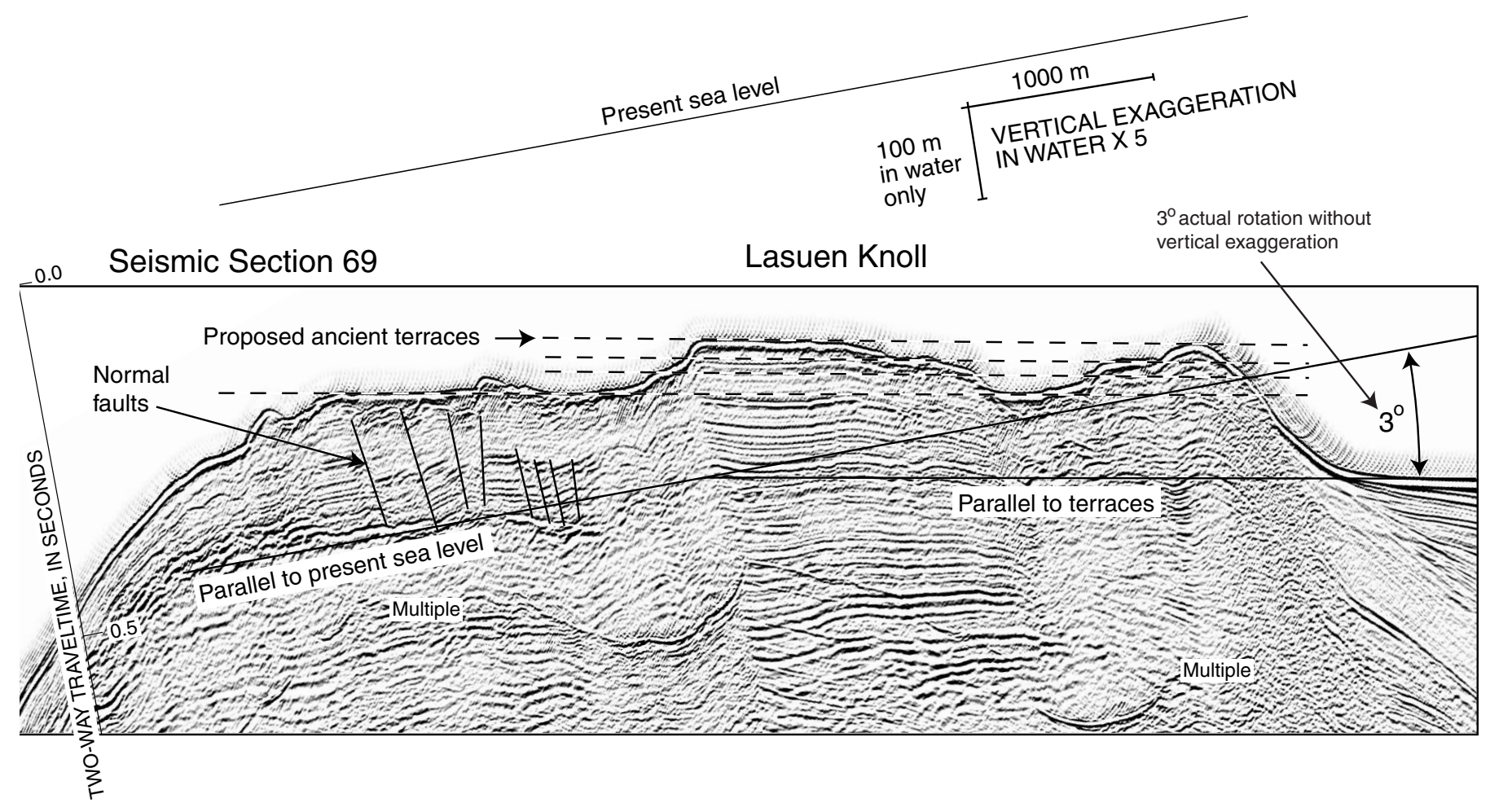

Figure 17. Detailed seismic section from near the crest of Lasuen Knoll, showing inferred wave-cut terraces. The seismic section is vertically exaggerated and has been rotated counter-clockwise by $10^{\circ}$, which corresponds to a $3^{\circ}$ rotation in natural coordinates, as annotated on the section. Section location is shown in figure 9. 
under Lasuen Knoll. The style of deformation that involves broad eastward tilting differs from the earlier, local folding and faulting that preceded cutting of the unconformity.

Another, transverse scarp (labeled in figs. 14A, B) is nearly perpendicular to the Palos Verdes Fault Zone. This scarp also has sharp edges and merges with the beginning of the sharp scarp that for nearly $30 \mathrm{~km}$ extends along the foot of the Lasuen Knoll and marks the location of the Palos Verdes Fault Zone. We propose that a fault underlies the transverse scarp and that it played a key role in the recent uplift of Lasuen Knoll.

A detailed view of the Palos Verdes Fault Zone near the north part of Lasuen Knoll (fig. 18) shows that this zone here includes at least four fault strands. The fault zone is about 1 $\mathrm{km}$ wide, and deep rocks ( $1.5 \mathrm{~s}$ traveltime) on the fault's west side are deformed anticlinally. The main, western fault strand is shown as vertical (pl. 1 and fig. 18), but complicated rock structure on both sides of this fault makes the interpretation ambiguous. This fault, however, might curve downward to dip west below the anticline. The right-hand part of seismic section 80 (pl. 1) shows rocks in the knoll truncated at the sea floor, as noted above for other parts of the knoll. Poorly reflective rocks make up the west part of the fault's upper plate (fig. 18). This loss of reflectivity could be due to high strain along closely spaced faults. Another possibility is that the poor reflectivity indicates an ancient landslide.

Southeast of the crest of Lasuen Knoll (seismic sections 69 and 70 on pl. 1), deep rocks on the west side of the Palos Verdes Fault Zone are faulted and folded. Younger rocks onlap these deep, deformed rocks with sharp angularity. The dip of the Palos Verdes Fault Zone in the area of seismic sections 69 and 70 is ambiguous but appears to be steep.

The Palos Verdes Fault Zone is difficult to trace southeast of Lasuen Knoll, partly because seismic lines are widely spaced, but also because the geologic structure is less distinct than farther northwest. Seismic section 213 (pl. 1), for example, shows only subdued sea-floor and structural relief, and reflections indicate several candidate features that could be the fault zone's southeastward extension. On the basis of the eastward curve of bathymetric contours that outline Lasuen Knoll between seismic lines 70 and 213 (see index map on pl. 1), the Palos Verdes Fault Zone might intersect seismic-reflection line 213 between SP 5000 and SP 6000. Another possibility is that motion on the Palos Verdes Fault Zone is transferred onto several fault splays southeastward from the knoll.

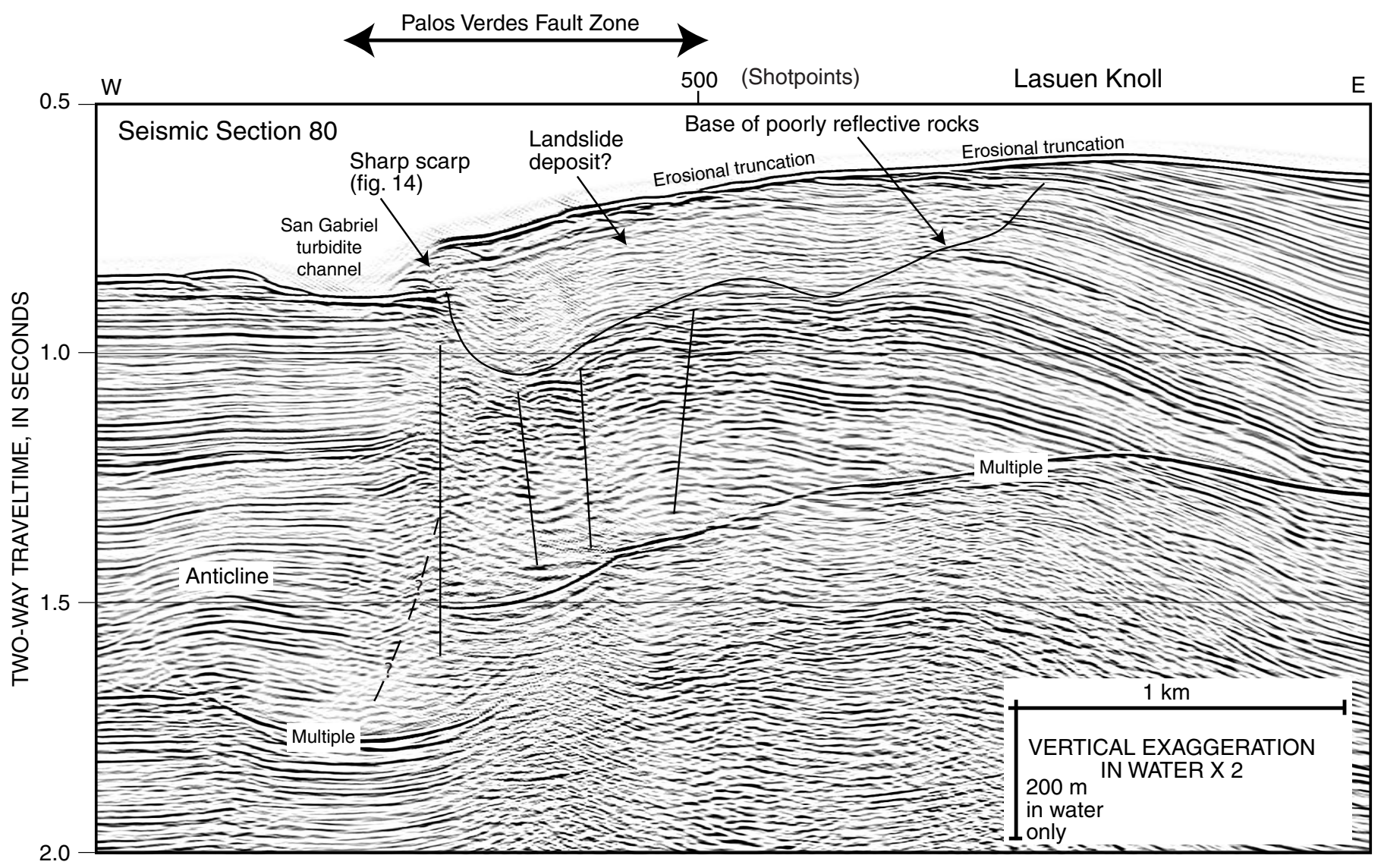

Figure 18. Detailed seismic section over the northwestern part of Lasuen Knoll, showing a scarp along the upper plate of the Palos Verdes Fault Zone and poorly reflective rocks that may be disrupted by closely spaced faulting or by a landslide. Section location is shown in figure 9. 


\section{Structural Belt West of the Palos Verdes Fault Zone}

The western structural belt includes rocks west of the Palos Verdes Fault Zone and under the western San Pedro Shelf, as well as those below the slope and within the deepwater San Pedro Basin (fig. 1). The western belt contains much evidence for strong deformation and active tectonics. For example, the floor of the San Pedro Sea Valley, a deep notch cut southwestward into the shelf edge, is covered by debris from recent submarine landslides. Furthermore, the main geologic structures include a large anticline and syncline (figs. 19 and 20) that border the Palos Verdes Fault Zone on the west.

The subshelf anticline grows in structural relief northwestward beneath the San Pedro Shelf. Projecting this anticline's axis (fig. 19) northwestward indicates that the axis would traverse the area where Miocene and Pliocene rocks crop out at the sea floor (Nardin and Henyey, 1978) (fig. 19) In addition, the projected axis would merge with the trend of the high topographic elevation of the Palos Verdes Peninsula.
The axis of the syncline under the west part of the San Pedro Shelf (fig. 19) can be extended northwestward along the axis of the San Pedro Sea Valley. This connection strongly suggests that the sea valley's location was controlled by the synclinal structure of underlying rocks. The walls of this valley, especially the north wall, are known to have spawned one or more submarine landslides (Locat and Lee, 2002). A debris avalanche, $14 \mathrm{~km}$ long and partly filling the San Pedro Sea Valley, occurred about 7,500 years ago and is much larger than more recent failures (Normark and others, 2002). The dips of rocks along both sea valley walls are toward the colinear axes of the syncline and sea valley. This inward dip probably explains why landslides were more commonly shed here than elsewhere along the San Pedro margin.

Seismic-reflection line 85 (fig. 20; location shown on figs. 2 and 9) provides a nearly perpendicular section through the anticline and syncline just described. Both structures are cut transversely by a swarm of normal faults that have offsets of less than about $100 \mathrm{~m}$. These faults extend to within a short distance of the sea floor, but do not appear to offset it.

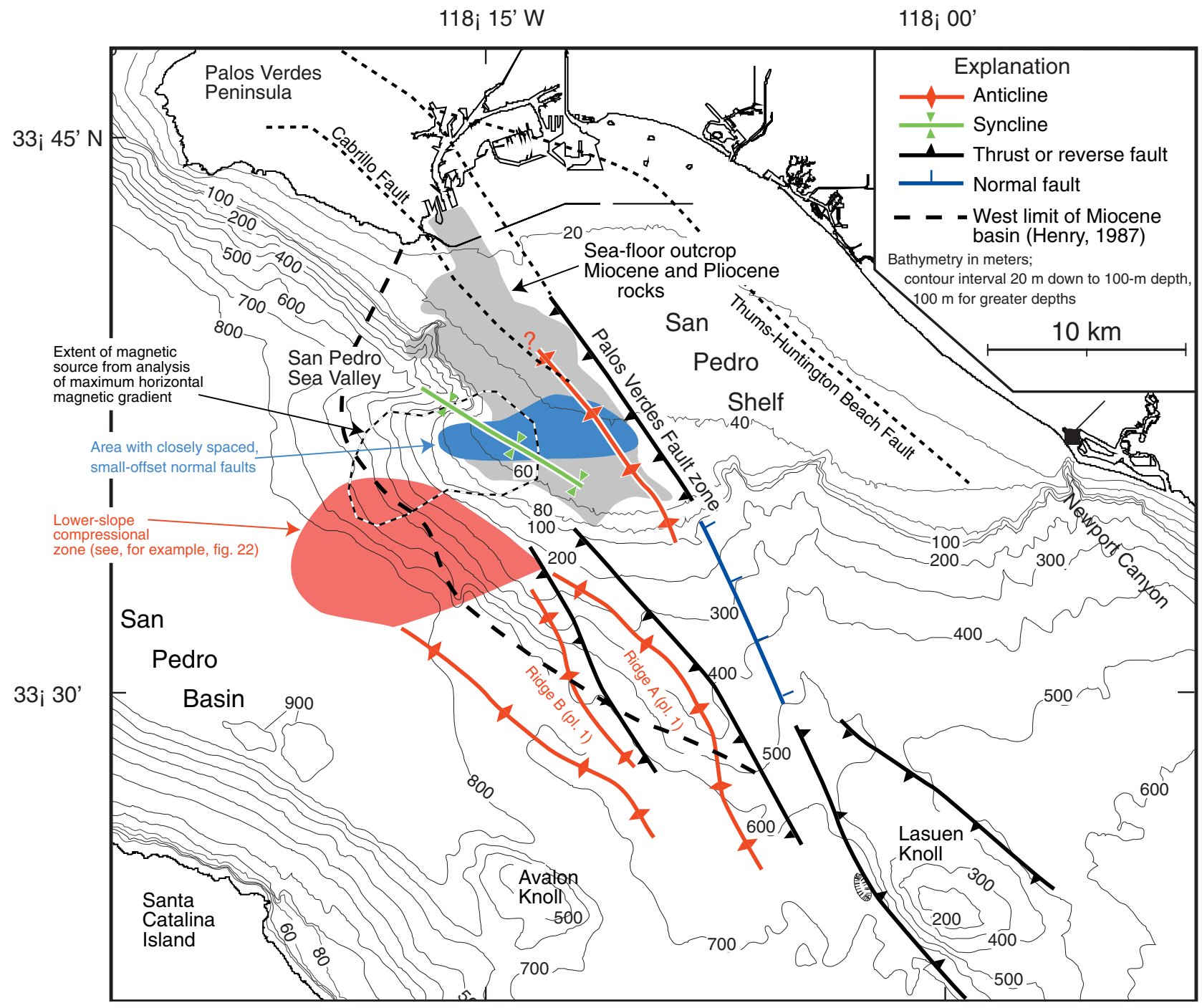

Figure 19. Map summarizing the main known and inferred structures in the region of the San Pedro Shelf and Lasuen Knoll. 
The origin of the swarm of normal faults is not obvious. Although the orientation of individual faults cannot be determined because of the coarse grid of seismic-reflection lines, as a group these faults affect an east-west trending zone below the shelf (fig. 19). This normal-fault zone has a peculiar orientation with respect to neighboring structures, in that it crosscuts the axes of the large anticline and syncline. Also, this zone in not obviously related to whatever rocks cause the western-shelf magnetic anomaly (fig. 8, top; causative body outlined in fig. 19). Olson (1974) describes potentially analogous structures - the Wilmington Anticline is cut transverse to strike by numerous small normal faults.

South of the San Pedro Shelf, an important category of fault lies west of and subparallel to the Palos Verdes Fault Zone. For example, the northeastward view of multibeam bathymetric data (fig. 14A) shows a sea-floor ridge, labeled "A," on the slope west of the Palos Verdes Fault Zone. Seismic-reflection sections 84 and 66 (pl. 1) show that this ridge is underlain by an anticline and by a west-dipping fault and that the anticline decreases in amplitude and radius of folding northwestward. Bathymetric data (fig. 14A) show that sea floor ridge A, and presumably its underlying fold and fault, is convex to the east. This convexity is located directly west of where normal-separation faults make up the Palos Verdes Fault Zone (fig. 19). An important point is that the sea-floor ridge has clearest expression and the underlying anticline has maximum relief directly west of where the Palos Verdes Fault Zone comprises a series of faults with normal separation. This structural arrangement, best depicted in seismic section 66 (pl. 1), suggests that these faults and folds are connected within a displacement-transfer zone, but our data are insufficient to unravel this connection.

Seismic-reflection data indicate little or no vertical movement during the recent past along faults associated with sea-floor ridge A. Many small-offset normal faults cut rocks forming the west flank of the ridge (fig. 13A). A Huntec seismic-reflection section collected over these faults (fig. $13 D$ ) shows them cutting shallow rocks and sediment but not the sea floor. In addition, the east side of the sea-floor ridge is bounded at depth by a reverse fault that appears to dip west (seismic section 66 on pl. 1; fig. 13A). Huntec seismic-reflection data over the buried fault reveal a sharp angular discordance within shallow strata that blanket the fault (fig. 13D). Shallow strata above the discordance and fault are horizontal and have not been tilted by vertical fault motion, and some dipping strata (for example at $0.54 \mathrm{~s}$ traveltime on fig. $13 D$ ) extend unbroken across the fault.

The discontinuous sea-floor ridge labeled "B," revealed by bathymetric data (figs. $14 A, B$ ), is subparallel to and west of ridge $\mathrm{A}$, and ridge $\mathrm{B}$ is also underlain by anticline and west-dipping fault. Seismic section 84 (pl. 1) shows that rocks under ridge B are mainly deformed by an anticline. Section 65 (fig. 21; location shown on fig. 9), however, crosses the ridge farther northwest, where faulting is more readily evident. A fault (below SP 5100 on fig. 21) is clearly expressed by the different appearance of reflections from the rock masses the fault separates. This seismic section shows that the fault dips steeply west, and this fault's tip is covered by only a thin sediment drape, indicating relatively recent activity.

Rocks under the slope and west of ridge B dip west and are truncated at the sea floor along the narrow crest of the ridge (fig. 21 , seismic section 65). These rocks have the "Miocene" reflective appearance that was described above, in which the reflections are strong, parallel, uniform in appearance, and continuous over long distances. Multibeam bathymetric data (fig. 14A) show approximately where these rocks are truncated along the lower slope of the San Pedro margin. We propose that the sea-floor truncation of indurated, Miocene(?) rocks evident on seismic section 65 and on other nearby sections occurred subaerially.

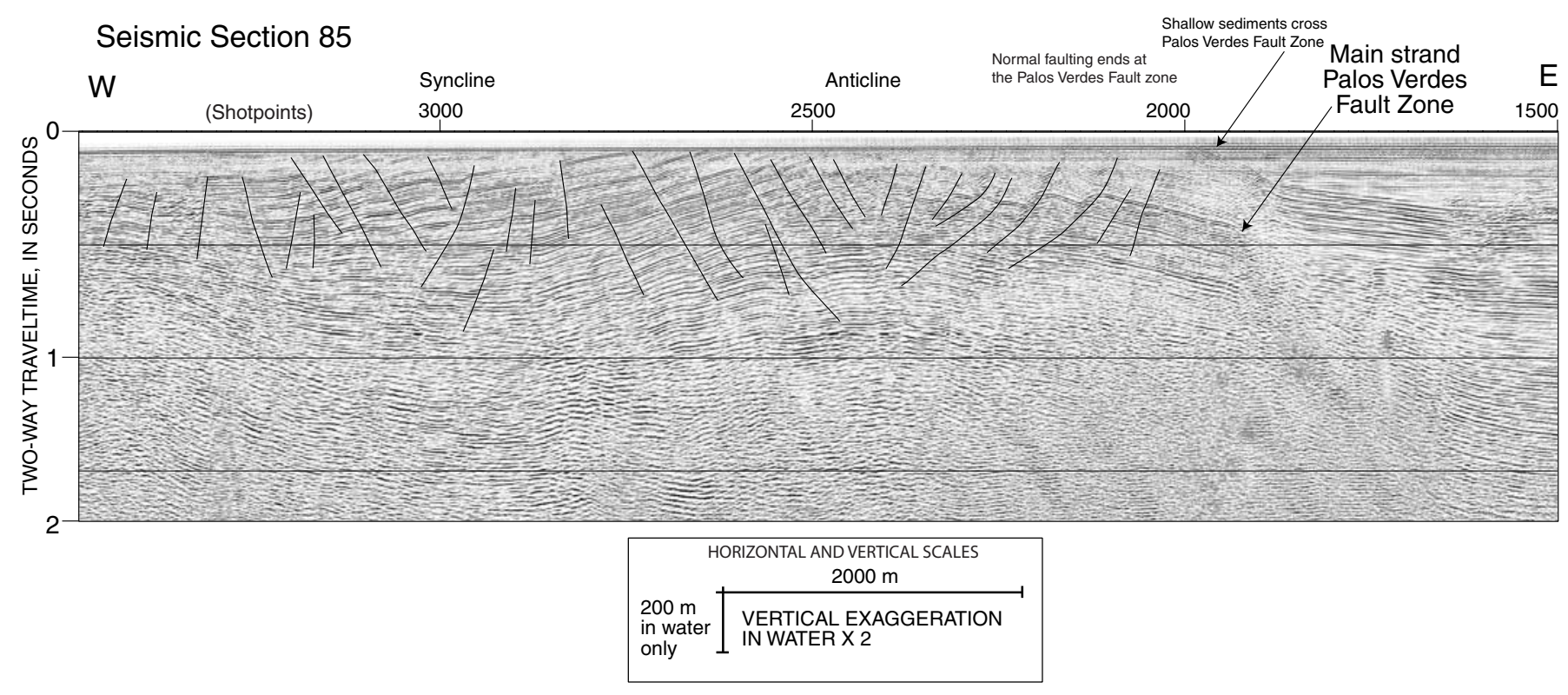

Figure 20. Detailed seismic section from the San Pedro Shelf, showing the large anticline and syncline that border the Palos Verdes Fault Zone (fig. 19). These structures are cut by numerous, small normal faults. Section location is shown in figure 9. 
Rocks under the slope, between the shelf break and the flat sea floor over the San Pedro Basin, produce reflections that are continuous for about $2 \mathrm{~km}$ (fig. 21, at traveltimes between 1.0 and $1.5 \mathrm{~s}$ below SP 5700 in seismic section 65), but these rocks end abruptly to the east against a rock mass that returns only few reflections. One interpretation of this reflection geometry is that the abrupt end of reflections reveals buried relief of deep rocks, possibly metamorphic basement or Miocene volcanic rocks.

Some rocks under the slope have the "Miocene" reflective appearance and pinch out westward in an obvious wedge (fig. 21, seismic sections 65 and 37). The apex of the wedge probably marks the western limit of the basin that contained the Miocene rocks. This interpretation accords with Henry (1987), who shows the regional extent of the Miocene basin edge near the Palos Verdes Peninsula and San Pedro Shelf (reproduced in fig. 19).

The lower-slope compressional zone (fig. 19) includes complicated deformation of rocks that underlie the slope and a small part of the San Pedro Basin (fig. 22; location of seismic section is shown in fig. 9). This compressional zone is about $8 \mathrm{~km}$ wide, and structural growth therein has produced a complicated stratigraphy with numerous unconformities and other bed truncations. Folds and thrust faults within the zone appear to belong to two generations. Some deep-seated faults, like the one below SP 3800 (fig. 22), appear to be inactive because they do not extend upward to deform rocks at or at near the sea floor. Other faults (for example, below SP's 3000 and 3500 in fig. 22) are part of a younger generation that arches the sea floor and deforms shallow sediment. Seismic-reflection data shown here lack the penetration to determine how these structures are related at depth, but we propose that they merge into a decollement.

A regionally flat sea floor at a depth of about $800 \mathrm{~m}$ characterizes the eastern part of the San Pedro Basin (fig. 19), which contains turbidite sediment and rocks that are little deformed except near the lower-slope compressional zone. Away from that zone, seismic section 86 (fig. 23, bottom)
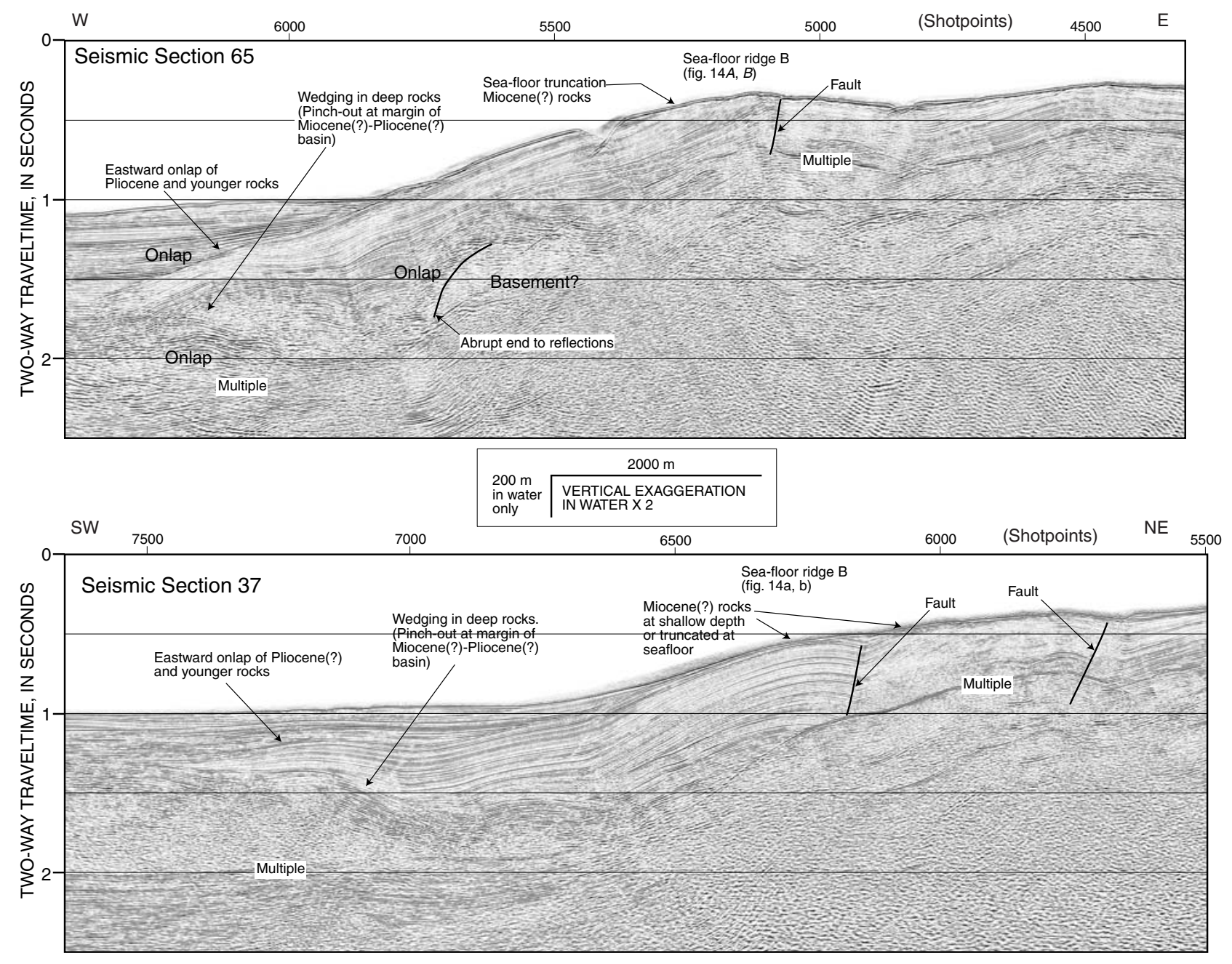

Figure 21. Seismic sections over the slope west of the San Pedro Shelf, showing what may be Miocene(?) rocks at shallow subsurface depth or truncated at the sea floor, and the wedging of Miocene(?) rocks at the margin of the basin in which they were deposited. Locations of sections are shown in figure 9. 


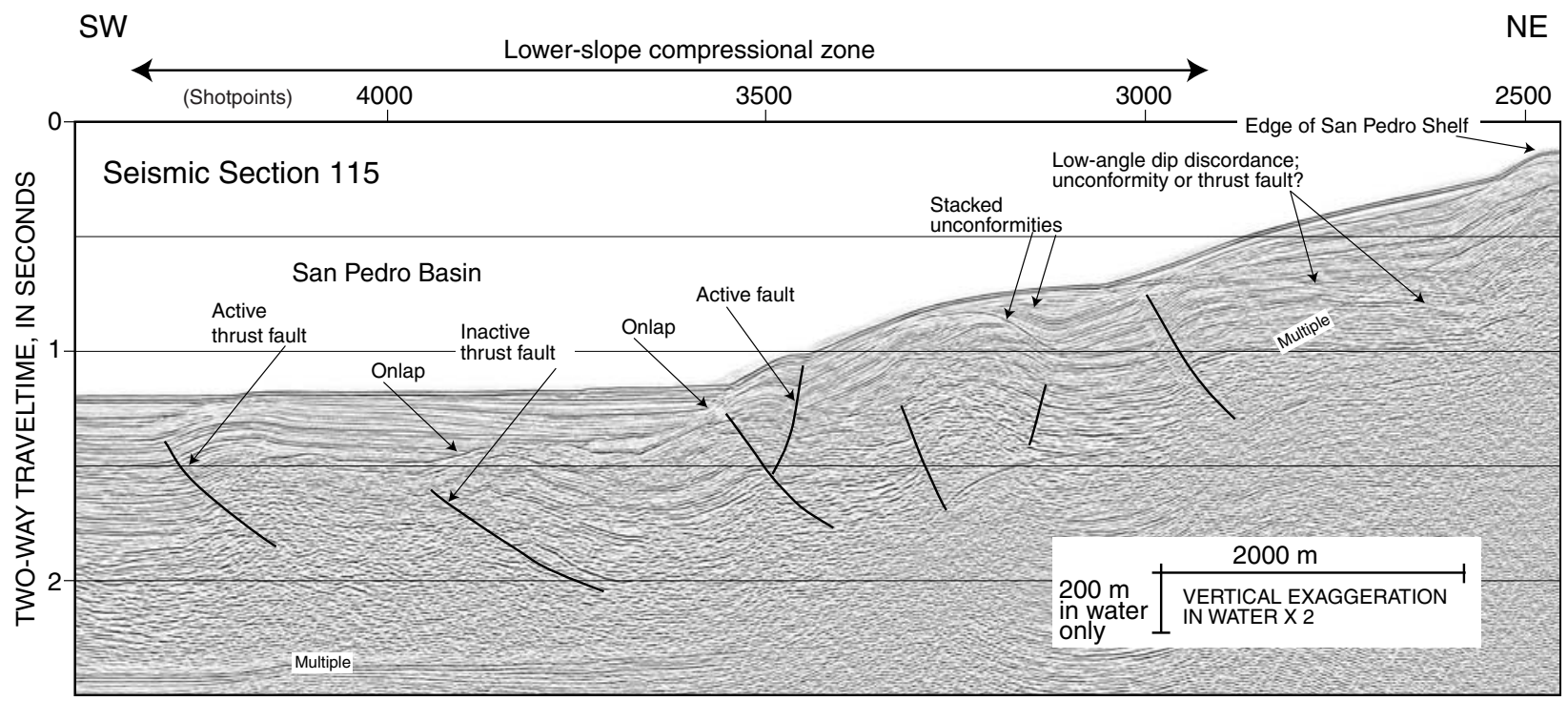

Figure 22. Seismic section over the slope west of the San Pedro Shelf, showing the lower-slope compressional zone. Section location is shown in figure 9 .
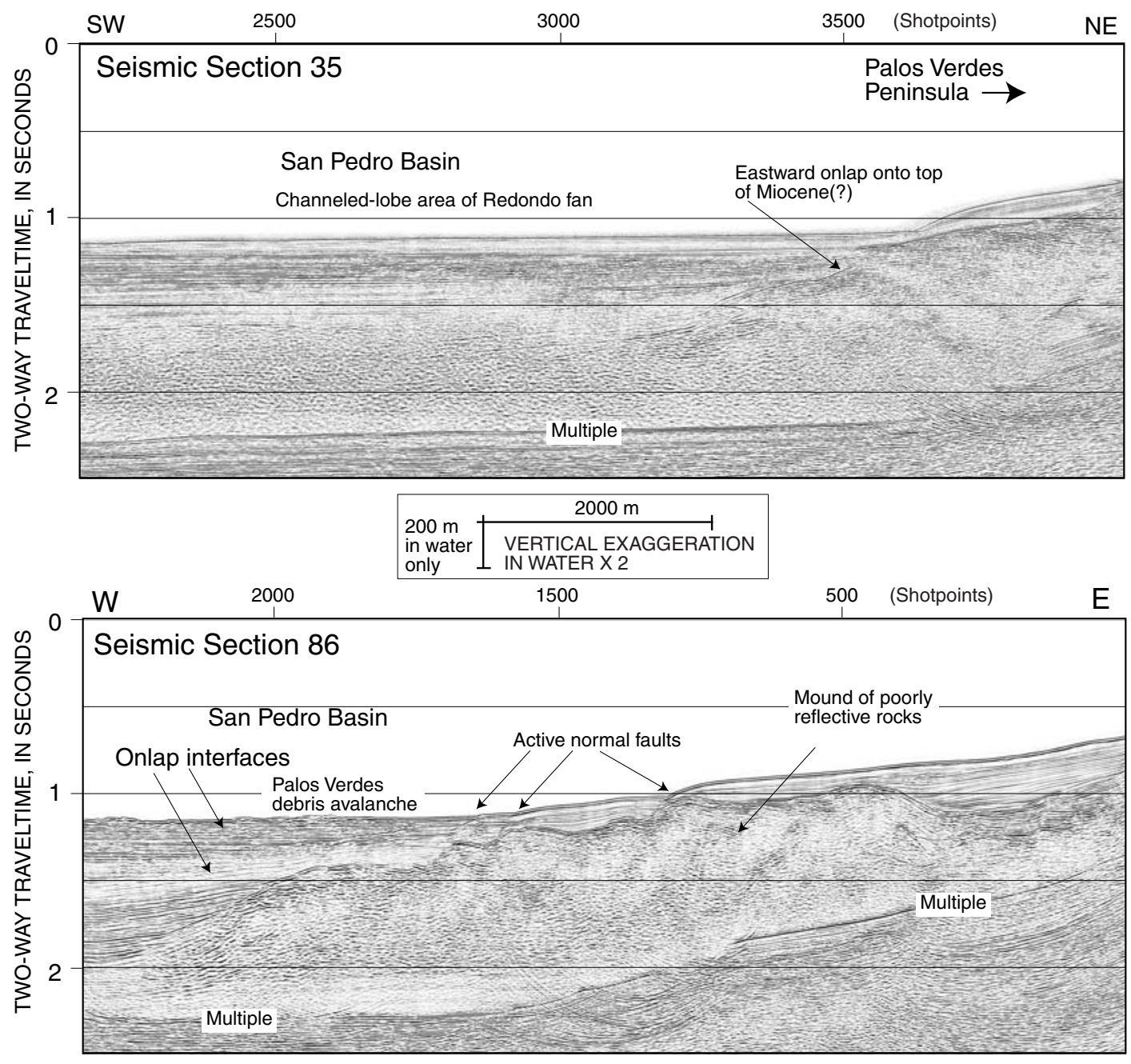

Figure 23. Seismic sections over the slope northwest of the San Pedro Shelf and the San Pedro Basin. The shallow part of the fill in the San Pedro Basin that is shown in seismic section 86 includes the Palos Verdes debris avalanche. Locations of sections are shown in figure 9. 
shows normal faults that cut shallow sediment or the sea floor, particularly below SP 1500. These faults extend downward and offset the irregular top of a mound of poorly reflective rocks. Basin fill and rocks under the slope onlap this mound's east and west flanks.

Seismic-reflection data collected along line 35 (fig. 23, top; location shown in fig. 9) suggested the possibility that the geology known from the Palos Verdes Peninsula (Woodring and others, 1946) extends into the offshore area. In general, a high level of low-frequency noise in these data prevents insightful interpretation of the deeper geology. Seismic section 35 , however, does show an unconformity that is at a traveltime of about $1.3 \mathrm{~s}$ below SP 3500. This unconformity dips southwest within or below the San Pedro Basin. Sedimentary fill overlying the unconformity is nearly horizontal, and dip discordance across the unconformity can be traced westward to about the center of this seismic section (SP 3000), where the unconformity's reflection has a traveltime of about $1.8 \mathrm{~s}$. We propose that Miocene rocks, like those exposed on the Palos Verdes Peninsula, underlie this unconformity.

\section{Discussion}

\section{Geology of the San Pedro Shelf}

The regional shelf structure described above has been combined with other geological and geophysical information to describe the geology of the San Pedro Shelf, to a maximum depth of about $2 \mathrm{~km}$. Two post-stack-migrated seismic sections converted from time to depth (pl. 2) formed the basis for modeling of aeromagnetic and gravity anomalies (figs. 8 and 24) to probe parts of the subsurface that are nonreflective. These results, when combined with stratigraphic information derived from sea-floor rock samples (Nardin and Henyey, 1978) and from drilling at the Beta oil field (Wright, 1991), yielded cross sections in depth, shown with only moderate $(2: 1)$ vertical exaggeration (pl. 2).

Both seismic sections in plate 2 cross the source of a large aeromagnetic anomaly (fig. 8; index map on pl. 2). In the area of this anomaly on both seismic sections, rocks are poorly reflective below about $0.5 \mathrm{~km}$ (pl. 2). Because of the absence of information in the seismic-reflection data about the deeper structure and rock types, we modeled aeromagnetic and gravity anomalies along these two sections.

Seismic-reflection data were used to constrain the models by placing the top of the magnetic source rock at the base of the shallow $(<0.5 \mathrm{~km})$ reflective strata. Sedimentary rocks are usually weakly magnetic, and therefore the source of the magnetic anomaly is unlikely to be shallower than $0.5 \mathrm{~km}$. Assuming reasonable magnetizations, which are based on measurements of a wide variety of rock samples, the resulting magnetic models (fig. 24) indicate that a large mass, as thick as $5.5 \mathrm{~km}$, of moderately to strongly magnetic rock underlies the outer part of the San Pedro Shelf (pl. 2).
The most likely source for the magnetic anomaly is middle Miocene basalt. Susceptibility measurements as high as $0.0019 \times 10^{-3} \mathrm{cgs}$ units made on basalt samples indicate that these rocks are moderately to strongly magnetic. Catalina Schist, which forms the crystalline basement in this region, does not produce significant aeromagnetic anomalies where exposed on Catalina Island (fig. 8, top). Supporting the idea that the magnetic source is basalt, the other high-amplitude aeromagnetic anomaly in the study area, near the northern part of the Palos Verdes Peninsula, is adjacent to exposures of Middle Miocene basalt on the Palos Verdes Peninsula (see, for example, Woodring and others, 1946). The exposed basalts themselves do not produce large-amplitude anomalies, but a nearby well drilled within the high-amplitude, nearshore aeromagnetic anomaly encountered a minimum thickness of $1 \mathrm{~km}$ of basalt (Dibblee, 1999). This implies that a significant thickness of basalt is needed to produce an aeromagnetic anomaly of equivalent amplitude and areal extent as the anomaly traversed by the seismic sections on the outer San Pedro Shelf.

The gravity map and models indicate that the magnetic source rocks do not produce an associated gravity high. This lack of correspondence may be an artifact of the grid size of the gravity data $(3 \mathrm{~km})$, which may be too coarse to resolve such a localized mass. However, density measurements of Tertiary basalt near the Los Angeles Basin indicate an average density of only $2.58 \mathrm{~g} / \mathrm{cm}^{3}$ (29 samples), which is substantially less dense than the Catalina Schist but greater than our modeled density. Thus, the lack of an associated gravity high is most likely a result of the basalt's low density. The modeled geometry of the basalt suggests that the source of the outershelf anomaly includes intrusive rocks, because the magnetic rock extends deeper into the subsurface than the depth extent of the adjacent sedimentary deposits.

The compiled seismic-reflection, potential-field, and stratigraphic data sets give considerable insight into the geology of the San Pedro Shelf (pl. 2). First, magnetic models indicate that the subshelf basalt is as thick as $5 \mathrm{~km}$ (fig. 24; in pl. 2, we chose to end the magnetic bodies downward at $3 \mathrm{~km}$ ), although in modeling magnetic data, a tradeoff can be made between body magnetizaton and thickness. Even so, basalt probably makes up a substantial part of the thickness of the upper crust.

The second main result is the difference in rock deformation around the magnetic body. Stratified rocks of probable Miocene age that directly overlie the magnetic body are deformed by short-wavelength folds and are offset along small faults of undetermined dip and throw (see, for example, pl. 2 , section 115, SP 2200). In contrast, stratified Miocene and Pliocene sedimentary rocks east of the magnetic mass are deformed into the large anticline and syncline that underlie the northern part of the San Pedro Shelf (pl. 2, section 115; fig. 19). The east flank of the magnetic body marks the juncture between the differently folded rocks. Seismic section 200 (pl. 2) shows the same relationship among folded rocks, except for the complication that the style of folding changes abruptly along a fault east of the magnetic body (pl. 2, seismic section 


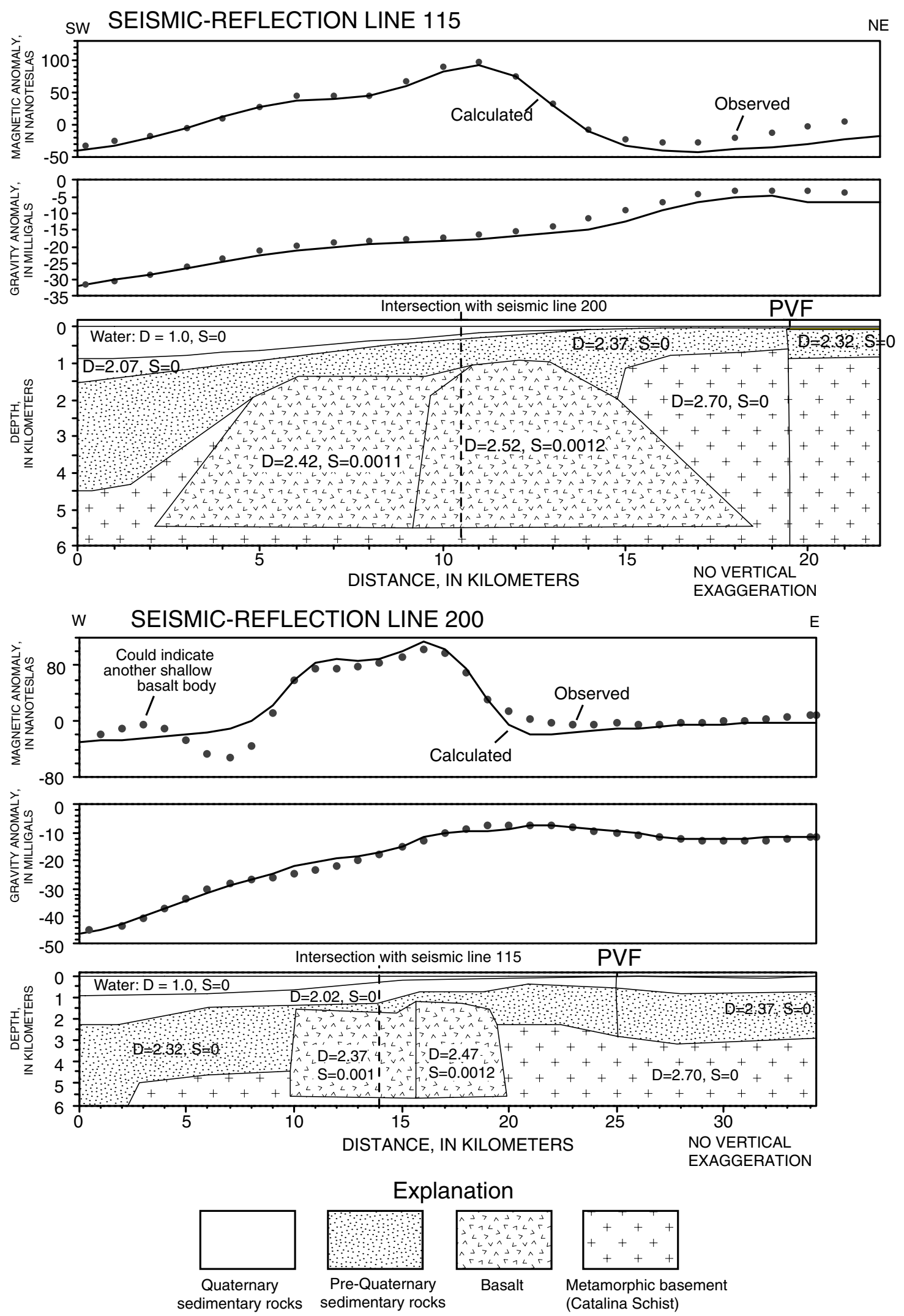

Figure 24. Magnetic and gravity models (2.5-dimensional) along seismic sections 115 (top) and 200 (bottom). D refers to the density of the body in $\mathrm{g} / \mathrm{cm}^{3} ; S$ is the susceptibility assigned to the body in $10-3 \mathrm{cgs}$ units. PVF, Palos Verdes Fault Zone. Differences in physical properties assigned to the magnetic body (here labeled basalt) can be attributed to inadequate modeling of the three-dimensional shape of the source. 
200, SP 3800). This fault is the northwestward continuation of the fault that forms sea-floor ridge A (for example, pl. 1, seismic section 66, SP 3300). The zones of different folding may be unrelated, in the sense that all folds may be relatively old and are now fortuitously juxtaposed across this fault (pl. 2, seismic section 200, SP 3800). On the other hand, the zones may mean that the basalt(?) was more competent mechanically than the encasing sedimentary rocks and thereby exerted considerable influence on the style of deformation.

Following this vein of thought, there may be a genetic link among the mass of magnetic rocks, the lower-slope compressional zone, which extends along the southwest margin of the magnetic rocks (figs. 19, 22), and the puzzling east-west zone of numerous small normal faults, which lies along the east margin of the basalt(?) (figs. 19, 20). For example, the distribution of compressive and extensional faulting (fig. 19) could have resulted from clockwise rotation and perhaps westward translation of the basalt(?) relative to its encasing sedimentary rock.

\section{Faults and Earthquake Hazards}

Achieving a full understanding of the earthquake threat posed by offshore faults near Los Angeles requires that substantial interpretive differences be resolved that now persist among researchers. For example, Namson and Davis (1990) and Shaw and Suppe (1996), among others, assume that only limited strike-slip movement occurs along major faults; they postulate instead that mainly thrust or reverse movement occurs at depth along blind faults. Such faults are commonly expressed at Earth's surface as broad folds and as discontinuous fault strands that may have styles of deformation and offset that are dissimilar to what occurs along the deeper, master faults. Using this faulting style, hypocenters 8 to $12 \mathrm{~km}$ deep are interpreted to lie along a downdip, southwestward projection of the Palos Verdes Fault Zone (Shaw, 1999); the aligned hypocenters show mainly reverse fault movement in this depth range.

Other researchers, however, emphasize the importance of strike- or oblique-slip offset (for example Nardin and Henyey, 1978; Wright, 1991; McNeilan and others, 1996; Francis and others, 1996; Bohannon and Geist, 1998). According to this view, movement along the Palos Verdes Fault Zone is mainly strike slip, and large positive structures have developed along it, possibly owing to restraining bends in the fault zone.

The controversy about predominant slip mode along faults remains unresolved because data presented here do not reveal sufficiently deep structural levels to unravel the relationships among offshore faults. In our view, however, the diversity in the near-surface structural expression of the Palos Verdes Fault Zone is best explained by movement along a deep strike-slip fault.

Using seismic-reflection data presented here, the offshore stretch of the Palos Verdes Fault Zone can be divided into three segments on the basis of the fault zone's structure in the upper $2 \mathrm{~km}$ of the crust. The northwestern segment underlies the San Pedro Shelf (fig. 19), where the shallow fault zone is vertical or dips steeply west. The middle fault-zone segment underlies the bathymetric saddle that separates the San Pedro Shelf from Lasuen Knoll. The fault zone in this segment is made up of east-dipping faults with normal separation. Near Lasuen Knoll, the southeastern segment of the Palos Verdes Fault Zone shows reverse separation and locally dips east at shallow angles, but along much of the knoll's west scarp, the fault zone appears to dip steeply.

The northwest segment of the Palos Verdes Fault Zone evidently deforms young rocks and the sea floor (McNeilan and others, 1996; Clarke and others, 1998). Along this part of the fault zone, some high-resolution seismic-reflection data (Francis and others, 1996) reveal a restraining bend and attendant flower structure that coincides with a low sea-floor swale about 1-4 $\mathrm{m}$ high. This deformation apparently postdates submergence and erosion of the shelf during the past 10 k.y.

The middle segment of the Palos Verdes Fault Zone includes normal-separation faults under the slope that deepens southeastward from the San Pedro Shelf. These normal faults may have developed analogously to such faults in the Inglewood oil field, which is located along the strike-slip Newport-Inglewood fault. There, a central graben developed in the upper $1 \mathrm{~km}$ of the crust, at the crest of an anticline, where the main and underlying, strike-slip fault undergoes a minor (about $2^{\circ}-5^{\circ}$ ) change in strike (figures 19 and 20 in Wright, 1991). The normal-separation faults in the middle segment of the Palos Verdes Fault Zone probably formed within a releasing bend along a right-lateral strike-slip fault.

The middle segment of the Palos Verdes Fault Zone ends abruptly between the San Pedro Shelf and Lasuen Knoll, and near this end the modern San Gabriel Canyon is incised into the upper plate of the Palos Verdes Fault Zone, close to the fault zone's trace (fig. 15). Seismic-reflection data indicate that the channel has been in this position while the upper part of the sediment along the fault's east side was being deposited over a prominent unconformity. These observations require that as the channel meandered laterally, movement along the Palos Verdes Fault Zone involved little or no vertical separation, otherwise the channel would have been diverted elsewhere. This limitation does not preclude pure strike-slip movement along the fault zone, but the reverse fault evident under the channel (fig. 15) has had little or no vertical movement.

Along the southeast segment of the Palos Verdes Fault Zone, sharp sea-floor scarps bordering Lasuen Knoll, possible tilted wave-cut terraces, and disrupted shallow sediment all attest to recent fault movement. Lasuen Knoll appears to be underlain by a pop-up structure, like those that develop along a restraining bend or stepover in a strike-slip fault system.

Probable wave-cut terraces and fresh fault scarps evident near Lasuen Knoll indicate a complex history of vertical motion that will hinder efforts to decipher recent fault offset. The shallow unconformity along the west side of the Palos Verdes Fault Zone at Lasuen Knoll (fig. 16) suggests a sequence of events that includes sediment deposition, uplift, erosion, and then subsidence. The sharp fault scarps bordering Lasuen Knoll indicate renewed uplift that postdates the final subsidence. 
The Cabrillo Fault (fig. 19) extends at least as far offshore, southeast from the Palos Verdes Peninsula, as seismicreflection line 115, as indicated by Marlow and others (2000). In our seismic-reflection data, this fault lies along an obvious and abrupt change in the appearance of reflections from Miocene rocks (pl. 2, section 115, SP 800). The fault cannot be followed with certainty southeast of line 115 .

A maze of reverse faults that form the lower-slope compressional zone (figs. 18 and 22) appears to be restricted to the area of the margin that lies west of the San Pedro Shelf. Whether or not these discontinuous faults connect with deeper, more extensive faults that would constitute an earthquake hazard cannot be determined using our data.

Offshore faults that parallel the Palos Verdes Fault Zone include those that developed along with sea-floor ridges $\mathrm{A}$ and B (pl. 1). Ridge A has its greatest structural development due west of where normal-separation faults make up the Palos Verdes Fault Zone. These faults are probably linked in the subsurface and must be considered as a whole when evaluating earthquake hazards.

\section{Conclusions}

1. Geological and geophysical data reveal the structural geology and earthquake hazards of the area just offshore from the Los Angeles urban region. Prominent structures include the Wilmington Graben, the Palos Verdes Fault Zone, and faults below the western part of the shelf and slope.

2. In the shallow $(<2 \mathrm{~km})$ crust, the Palos Verdes Fault Zone is segmented into three parts. Under the San Pedro Shelf, the main fault strand in this zone dips west and is probably an oblique-slip fault. Southeast of the shelf, the fault zone comprises several normal-separation faults, most of which dip east. Near Lasuen Knoll, the Palos Verdes Fault Zone exhibits reverse separation and dips east at a low angle, and what appear to be fresh sea-floor scarps indicate recent fault movement. Such segmentation probably results from changes in geometry along a master strike-slip fault zone at depth. This segmentation could complicate efforts to apportion seismic hazard along this fault zone, because an earthquake rupture might not propagate across segment boundaries or the inferred, underlying fault bends.

3. Rocks under Lasuen Knoll and those under the Palos Verdes Peninsula are involved in concentrated deformation and uplift that may have occurred similarly. Both the relief of Lasuen Knoll and some secondary faults associated with this knoll terminate abruptly northward along a bathymetric scarp that is transverse to the Palos Verdes Fault Zone. In like fashion, the high relief of the Palos Verdes Peninsula ends abruptly along the south shore of Santa Monica Bay. Perhaps structures under the peninsula end along a transverse fault like the transverse one near Lasuen Knoll.
4. Seismic-reflection and multibeam bathymetric data reveal the extent of several other northwest-striking faults under the outer shelf and slope. These faults deform rocks into anticlines that have clear geomorphic expression as sea-floor ridges. Evidence for recent movement along these faults is equivocal, because at many locations, undated sediment just under the sea-floor appears to be undeformed, indicating the absence of very recent fault movement.

5. Significant tsunamis can result from major submarine landslides, and the debris from one or more landslides is evident along the axis of the San Pedro Sea Valley. This sea valley follows the axis of a large syncline under the San Pedro Shelf, so that synclinal rocks, of probable Miocene age, dip toward the axis of the sea valley. This indicates that more landslides, and hence tsunamis, could occur because the synclinal rocks dip favorably for the development of coherent slide masses.

6. The stratigraphy under the San Pedro Shelf was determined by combining depth-converted seismic-reflection data with rock information from oil wells and sea-floor samples. Results show that east of the Palos Verdes Fault Zone the Wilmington Graben contains thick (as much as $1.5 \mathrm{~km}$ ) Quaternary deposits, whereas west of the fault zone Miocene and Pliocene rocks are truncated at the sea floor. Rocks under the slope are assigned provisional Miocene and Pliocene ages on the basis of reflection appearance, because these slope rocks have a distinctive reflectivity in which reflections are parallel, uniform in amplitude, and continuous over long distances. Provisionally dated Miocene and Pliocene rocks under the slope terminate in the west in a wedge that probably marks the margin of the basin in which these rocks were deposited.

7. Modeling of aeromagnetic data reveals a large magnetic body under the western part of the San Pedro Shelf and the adjacent upper slope. This body is probably Miocene basalt. The basalt mass may have influenced the deformation of sedimentary rocks that encase the mass. Sedimentary rocks that overlie the basalt are deformed into short-wavelength, small-amplitude folds, whereas sedimentary rocks east of the basalt mass are deformed into folds that have much longer wavelengths and greater amplitude. This difference in style of folding may have resulted because the basalt was more competent during deformation than the sedimentary rocks.

\section{Acknowledgments}

We thank Gary Fuis, Daniel Ponti, Craig Nicholson, and Thomas Brocher for critical comments on this report. Christina Gutmacher, Florence Wong, and Carolyn Degnan assisted our effort greatly in data collection, processing, and display. 


\section{References}

Aldridge, D. F., and Oldenburg, D. W., 1993, Two-dimensional tomographic inversion with finite-difference traveltimes: Journal Seismic Exploration, v. 2, p. 257-274.

Argus, D. F., Heflin, M. B., Donnellan, A., Webb, F. H., Dong, D., Hurst, K. J., Jefferson, D.C., Lyzenga, G. A., Watkins, M., and Zumberge, J. F., 1999, Shortening and thickening of metropolitan Los Angeles measured and inferred using geodesy: Geology, v. 27, p. 703-706.

Astiz, L., and Shearer, P. M., 2000, Earthquake locations in the inner Continental Borderland, offshore Southern California: Bulletin of the Seismological Society of America, v. 90, p. 425-449.

Atwater, T. M. 1970, Implications of plate tectonics for the Cenozoic evolution of western North America: Geological Society America Bulletin, v. 81, p. 3513-3536.

Barron, J. A., and Isaacs, C.M., 2001, Updated chronostratigraphic framework for the California Miocene, in Isaccs, C.M., and Rullkotter, J., eds., The Monterey Formation from rocks to molecules: New York, Columbia University Press, p. 393-395.

Barrows, A.G., 1974, A review of the geology and earthquake history of the Newport-Inglewood structural zone, southern California: California Division of Mines and Geology Special Report 114, 115 p.

Bjorklund, T., Burke, K., Zhou, H., and Yeats, R. S., 2002, Miocene rifting in the Los Angeles Basin-evidence from the Puente Hills half-graben, volcanic rocks, and P-wave tomography: Geology, v. 30, p. 451-454.

Blake, G.H., 1991, Review of the Neogene biostratigraphy and stratigraphy of the Los Angeles Basin and implications for basin evolution, in Biddle, K.T., ed., Active Margin Basins: American Association Petroleum Geologists Memoir 52, p. 135-184.

Bohannon, R. G., and Geist, E. L., 1998, Upper crustal structure and Neogene tectonic development of the California Continental Borderland: Geological Society of America Bulletin, v. 110, p. 779-800.

Brocher, T. M., Clayton, R. W., Klitgord, K. D., Bohannon, R. G., Sliter, R., McRaney, J. K., Gardner, J. V., and Keene, J. B., 1995, Multichannel seismic-reflection profiling on the R/V Maurice Ewing during the Los Angeles Region Seismic Experiment (LARSE), California: U.S. Geological Survey Open-File Report 95-228, 70 p.

Bryan, M. E., 1987, Emergent marine terraces and Quaternary tectonics, Palos Verdes Peninsula, California, in Fischer, P.J., ed., Geology of the Palos Verdes Peninsula and San Pedro Bay: Pacific Section SEPM and AAPG Field Trip Guide Book 55, p. 63-78.
Clarke, S. H., Kennedy, M. P., Ponti, D. J., Moody, C., and Wilson, J., 1998, Kinematics of the Palos Verdes Fault Zone in Los Angeles Harbor, California, from multidisciplinary studies: Geological Society America Abstracts with Program, v. 30, no. 5, p. 9-10.

Conrad, C.L., and Ehlig, P. L., 1987, The Monterey Formation of the Palos Verdes Peninsula, California-an example of sedimentation in a tectonically active basin within the California Continental Borderland, in Fischer, P.J., ed., Geology of the Palos Verdes Peninsula and San Pedro Bay: Pacific Section of the Society of Economic Paleontologists and Mineralogists, Book 55, p. 17-30.

Crouch, J.K., and Suppe, J., 1993, Late Cenozoic tectonic evolution of the Los Angeles Basin and inner California borderland-A model for core complex-like crustal extension: Geological Society America Bulletin, v. 105, p. 1415-1434.

Davis, T., and Namson, J., 2002, Nine regional cross sections across the Los Angeles Basin. [URL http:// www.davisnamson.com/downloads/index.htm]

Dibblee, T. W., Jr., 1999, Geologic map of the Palos Verdes Peninsula and vicinity, Redondo Beach, Torrance and San Pedro quadrangles, Los Angeles County, California: Dibblee Geological Foundation, map no. DF-70.

Dickinson, W. R., 1997, Tectonic implications of Cenozoic volcanism in coastal California: Geological Society of America Bulletin, v. 109, p. 936-954.

Dolan, J. F., Sieh, K., Rockwell, T. K., Yeats, R. S., and Shaw J., 1995, Prospects for larger more frequent earthquakes in greater metropolitan Los Angeles, California: Science, v. 267, p. 199-205.

Dolan, J. F., Sieh, K., and Rockwell, T.K., 2000, Late Quaternary activity and seismic potential of the Santa Monica fault system, Los Angeles, California: Geological Society America Bulletin, v. 112, p. 1559-1581.

Engebretson, D.C., Cox, A., and Gordon, R. G., 1985, Relative motions between oceanic and continental plates in the Pacific basin: Geological Society of America Special Paper 206, 59 p.

Fischer, P. J., 1992, Neotectonics of the Newport-Inglewood and Palos Verdes Fault Zones along the offshore margins of the greater Los Angeles Basin, in Stout, M.L., ed., American Association of Petroleum Geologists, 35 ${ }^{\text {th }}$ Annual Meeting, Proceedings, p. 603-613.

Fischer, P. J., Patterson, R. H., Darrow, C., Rudat, J. H., and Simila, G., 1987, The Palos Verdes Fault Zone-onshore to offshore, in Fischer, P.J., ed., Geology of the Palos Verdes Peninsula and San Pedro Bay, Pacific Section of the Society of Economic Paleontologists and Mineralogists and American Association of Petroleum Geologists Field Trip Guide Book 55, p. 91-134. 
Fisher, M.A., Normark, W.R., Bohannon, R. G., Sliter, R., and Calvert, A. J., in press, Geology of the continental margin beneath Santa Monica Bay, southern California, from seismic-reflection data, Bulletin Seismological Society America.

Francis, R.D., Legg, M. R., Sigurdson, D. R., and Fischer, P. J., 1996, Restraining bend along the Palos Verdes Fault Zone, offshore Southern California: Eos, Transactions, American Geophysical Union, v. 77, n. 46, Suppl., p. 512.

Fuis, G. S., Ryberg, T., Godfrey, N. J., Okaya, D. A., and Murphy, J. M., 2001, Crustal sructure and tectonics from the Los Angeles Basin to the Mojave Desert, southern California: Geology, v. 29, p. 15-18.

Gardner, J. V., and Dartnell, P., 2002, Multibeam mapping of the Los Angeles, California, margin: U.S. Geological Survey Open-File Report 02-162. [URL http: //geopubs.wr.usgs.gov/open-file/of02-162/index.html]

Godfrey, N.J., Fuis, G.S., Langenheim, V.E., Okaya, D.A., and Brocher, T.M., 2002, Lower-crustal deformation beneath the Transverse Ranges, southern California-results from the Los Angeles Regional Seismic Experiment: Journal of Geophysical Research, v. 107, p. 8-1 to 8-19.

Greene, H. G., and Kennedy, M.P., eds., 1987, Geology of the inner southern California continental margin: California Division of Mines and Geology, California Continental margin Geologic Map Series, scale 1:250,000.

Gutmacher, C. E., Normark, W.R., Ross, S.L., Edwards, B.D., Sliter, R., Hart, P., Cooper, B., Childs, J., and Reid, J. A., 2000, Cruise report for A1-00-SC Southern California earthquake hazards project, Part A: U.S. Geological Survey Open-File Report 00-516, 67p. [URL http: //geopubs.wr.usgs.gov/open-file/of00-516/of00-516p.pdf]

Hauksson, E. 1990. Earthquakes, faulting, and stress in the Los Angeles Basin: Journal of Geophysical Research, v. 95, p. $15365-15394$.

Hauksson, E., and Gross, S. J., 1991, Source parameters of the 1933 Long Beach earthquake: Bulletin of the Seismological Society of America, v. 81, p. 81-98.

Hauksson, E., Jones, L.M., and Hutton, K., 1995, The 1994 Northridge earthquake sequence in California-seismological and tectonic aspects: Journal of Geophysical Research, v. 100 , p. $12335-12355$.

Hauksson, E., Jones, L. M., Davis, T. L., Hutton, L.K., Brady, A.G., Reasenberg, P. A., Michael, A. J., and Yerkes, R. F., 1988, The 1987 Whittier Narrows earthquake in the Los Angeles metropolitan area, California: Science, v. 239, p. 1409-1412.
Henry, M. J., 1987, Los Angeles Basin-an overview, in Clarke, D., and Henderson, C., eds., Geologic field guide to the Long Beach area: Pacific Section American Association of Petroleum Geologists, Field Trip Guide Book 58, p. 1-29, 2 cross sections.

Hornafius, J. S., Luyendyk, B. P., Terres, R. R., and Kamerling, M. J., 1986, Timing and extent of Neogene tectonic rotation in the western Transverse Ranges, California: Geological Society of Amererica Bulletin, v. 97, p.1476-1487.

Isaacs, C.M., 2001, Depositional framework of the Monterey Formation, California, in Isaacs, C.M., and Rullkotter, J., eds., The Monterey Formation from rocks to molecules: New York, Columbia University Press, p. 1-30.

Jennings, C.W., 1994, An explanatory text to accompany the fault activity map of California and adjacent areas: California Division of Mines and Geology Geologic Data Map No. $6,92 \mathrm{p}$.

Kamerling, M.J., and Luyendyk, B.P., 1985, Paleomagnetism and Neogene tectonics of the northern Channel Islands, California: Journal of Geophysical Research, v. 90, no. B14, p. $12485-12502$.

Langenheim, V.E., Halvorson, P.F., Castellanos, E.L., and Jachens, R.C., 1993, Aeromagnetic map of the southern California borderland east of the Patton Escarpment: U.S. Geological Survey Open-File Report 93-250, scale 1: 500,000 .

Lin, J., and Stein, R. S., 1989, Coseismic folding, earthquake recurrence, and the 1987 source mechanism at Whittier Narrows, Los Angeles Basin, California: Journal of Geophysical Research, v. 94, p. 9614-9632.

Locat, J., and Lee, H. J., 2002, Submarine landslidesadvances and challenges: Canadian Geotechnical Journal, v. 39, p. 193-212.

Luyendyk, B. P., Kamerling, M.J., and Terres, R.R., 1980, Geometric model for Neogene crustal rotations in southern California: Geological Society America Bulletin, v. 91, p. 211-217.

Luyendyk, B.P., Kamerling, M.J., Terres, R.R., and Hornafius, J.S., 1985, Simple shear of southern California during the Neogene: Journal of Geophysical Research, v. 90, p. 1245412466.

Magistrale, H., Day, S., Clayton, R.W., and Graves, R., 2000, The SCEC southern California reference three-dimensional seismic velocity model version 2: Bulletin of the Seismological Society of America, v. 90, p. S5-S76.

Marlow, M.S., Gardner, J.V., and Normark, W.R., 2000, Using high-resolution multibeam bathymetry to identify sea floor surface rupture along the Palos Verdes Fault Zone complex in offshore southern California: Geology, v. 28, p. 587-590. 
McCulloh, T., Fleck, R. J., Denison, R. E., Beyer, L. A., and Stanley, R. G., 2002, Age and tectonic significance of volcanic rocks in the northern Los Angeles Basin, California: U.S. Geological Survey Professional Paper 1669, 24 p.

McNeilan, T. W., Rockwell, T. K., and Resnik, G., 1996, Style and rate of Holocene slip, Palos Verdes Fault Zone, Southern California: Journal of Geophysical Research, v. 101, p. 8317-8334.

Namson, J. S., and Davis, T. L., 1990, Late Cenozoic fold and thrust belt of the southern Coast Ranges and Santa Maria basin, California: American Association Petroleum Geologists Bulletin, v. 74, p. 467-492.

Nardin, T. R., and Henyey, T. L., 1978, Pliocene-Pleistocene diastrophism of Santa Monica and San Pedro shelves, California continental borderland: American Association Petroleum Geologists Bulletin, v. 62, p. 247-272.

Nicholson, C., Sorlien, C., Atwater, T., Crowell, J. C., and Luyendyk, B. P., 1994, Microplate capture, rotation of the western Transverse Ranges, and initiation of the San Andreas transform as a low-angle fault system: Geology, v. 22, p. 491-495.

Normark, W. R., Bohannon, R. G., Sliter, R., Dunhill, G., Scholl, D. W., Laursen, J., Reid, J. A., and Holton, D., 1999a, Cruise report for A1-98-SC Southern California earthquake hazards project: U.S. Geological Survey OpenFile Report 99-152, 60 p.

Normark, W. R., Reid, J. A, Sliter, R. W., Holton, D., Gutmacher, C. E., Fisher, M. A., and Childs, J. R., 1999b. Cruise Report for 01-99-SC: Southern California earthquake hazards project, U.S. Geological Survey Open-File Report No. 99-560, 54 p. [URL http://geopubs.wr.usgs.gov/openfile/of99-560/]

Normark, W.R., Sliter, R., and McGann, M., 2002, Emplacement of the 7,500 yr B.P. Palos Verdes submarine debris avalanche, southern California: Eos, Transactions, American Geophysical Union, Fall Meeting Supplement, v. 83, n. 47, p. T71E-1219.

Olson, L.J., 1974, Belmont offshore oil field: California Division of Oil and Gas Publication TP01, p. 1-14.

Petersen, M.D., and Wesnousky, S.G., 1994, Fault slip rates and earthquake histories for active faults in southern California: Bulletin Seismological Society America, v. 84, p. 1608-1649.

Richards-Dinger, K.B., and Shearer, P.M., 2000, Earthquake locations in southern California obtained using source-specific station terms: Journal Geophysical Research, v. 105, p. 10939-10960.
Schneider, C.L., Hummon, C., Yeats, R. S., and Huftile, G. L., 1996, Structural evolution of the northern Los Angeles Basin, California, based on growth strata: Tectonics, v. 15, p. 341-355.

Schwartz, D. E., and Colburn, I. P., 1987, Late Tertiary to Recent chronology of the Los Angeles Basin, southern California, in Fischer, P.J., ed., Geology of the Palos Verdes Peninsula and San Pedro Bay: Pacific Section of the Society of Economic Paleontologists and Mineralogists and American Association of Petroleum Geologists Field Trip Guide Book 55, p. 5-16.

Shaw, J. H., 1999, Seismic-reflection transect and geologic cross section across the central Los Angeles Basin and San Pedro Bay: Annual Report, 1999, to the Southern California Earthquake Center, 2 p., 1 sheet. [URL http://www.scec.org/ research/99research/99shaw.pdf]

Shaw, J. H., and Shearer, P. M., 1999, An elusive blind-thrust fault beneath metropolitan Los Angeles: Science, v. 283, p. 1516-1518.

Shaw, J. H., and Suppe, J., 1996, Earthquake hazards of active blind-thrust faults under the central Los Angeles Basin, California: Journal Geophysical Research, v. 101, p. 86238642 .

Stanley, R.G., Wilson, D. S., and McCrory, P. A., 2000, Locations and ages of middle Tertiary volcanic centers in coastal California: U.S. Geological Survey Open-File Report 00$154,27 \mathrm{p}$.

Stephenson, W. J., Rockwell, T. K., Odum, J. K., Shedlock, K. M., and Okaya, D. A., 1995, Seismic-reflection and geomorphic characterization of the onshore Palos Verdes Fault Zone, Los Angeles, California: Bulletin Seismological Society of America, v. 85, p. 943-950.

Suess, M.P., and Shaw, J. H., 1998, High resolution modeling of seismic velocities in the Los Angeles Basin: American Geophysical Union Fall Meeting, Poster S21C-03. [URL http://structure.harvard.edu/SCEC/sonic_la.html]

ten Brink, U. S., Zhang, J., Brocher, T. M., Okaya, D. A., Klitgord, K. D., and Fuis, G. S., 2000, Geophysical evidence for the evolution of the California inner continental borderland as a metamorphic core complex: Journal of Geophysical Research, v. 105, p. 5835-5857.

Truex, J. N., 1973, Structural evolution of Wilmington anticline, California [abs.]: American Association of Petroleum Geologists Bulletin, v. 57, p. 809.

Tsutsumi, H., Yeats, R. S., and Huftile, G. J., 2001, Late Cenozoic tectonics of the northern Los Angeles fault system, California: Geological Society America Bulletin, v. 113, p. 454-468. 
Vedder, J. G. 1987, Regional geology and petroleum potential of the southern California borderland, in Scholl, D.W., Grantz, A., and Vedder, J. G., eds., Geology and resource potential of the continental margin of western North America and adjacent ocean basins-Beaufort Sea to Baja California: Circum-Pacific Council for Energy and Mineral Resources Earth Science Series, v. 6, p. 403-448.

Walls, C., Rockwell, T., Mueller, K., Bock, Y., Williams, S., Pfanner, K. J., Dolan, J., and Fang, P., 1998, Escape tectonics in the Los Angeles metropolitan region and implications for seismic risk: Nature, v. 394, p. 4485-4495.

Ward, S. N., and Valensise, G., 1994, The Palos Verdes terraces, California-bathtub rings from a buried reverse fault: Journal of Geophysical Research, v. 99, p. 4485-4494.

Weaver, K. D., and Dolan, J. F., 2000, Paloeseismology and geomorphology of the Raymond Fault, Los Angeles County, California: Bulletin Seismological Society of America, v. 90, p. 1409-1429.
Woodring, W. P., Bramlette, M. N., and Kew W. S. W., 1946, Geology and paleontology of the Palos Verdes Hills, California: U.S. Geological Survey Professional Paper 207, 145 p.

Wright, T. L., 1991, Structural geology and tectonic evolution of the Los Angeles Basin, California, in Biddle, K. T., ed., Active margin basins: American Association of Petroleum Geologists Memoir 52, p. 35-134.

Yerkes, R. F., McCulloh, T. H., Schoelhamer, J. E., and Vedder, J. G., 1965, Geology of the eastern Los Angeles Basin, southern California: U.S. Geological Survey Professional Paper 420-A, 57 p.

Ziony, J. I., and Jones, L. M., 1989, Map showing late Quaternary faults and 1978-1984 seismicity of the Los Angeles region, California: U.S. Geological Survey Miscellaneous Field Studies Map MF-1964, 1 sheet, scale 1:250,000. 
${ }^{\star}{ }_{\text {science }}^{\star} 5^{\star}$ for America 